\title{
Od surowych danych do wizualizacji. Baza danych do dziejów mieszkańców lubelskiego Podzamcza z lat 1633-1733
}

ZARYS TREŚCI: $\quad$ W artykule omówiono korzyści płynące z analizowania danych źródłowych przy wykorzystaniu edycji bazodanowych oraz możliwości istniejące w tego typu projektach badawczych. Artykuł przybliża kilka przykładowych historii rodzin i charakterystycznych miejsc Podzamcza oraz grupuje dane statystyczne według wybranych kryteriów, m.in. kierunku migracji i dynamiki napływu ludności oraz różnorodności rzemiosł i profesji pozyskanych z bazy danych.

sŁowA KLUCzowe: baza danych, big data, socjotopografia, genealogia, Żydzi, chrześcijanie, Podzamcze, Lublin

ABSTRACT:

The article discusses the advantages of analyzing source data while using database publications, as well as the possibilities present in such research projects. The article describes several examples of family histories and characteristic places in the Podzamcze district [settlements at the foot of the castle] and categorizes statistical data in accordance with selected criteria, inter alia the direction of population migration and influx, and with the diversity of crafts and professions collected from the database.

Keywords database, Big Data, sociotopography, genealogy, Jews, Christians, Podzamcze, Lublin 


\section{Wstęp}

Grodzkie akta sądowe z XVII i XVIII w. są niezastąpionym źródłem do badań nad historią prawa, ustroju, mechanizmów władzy, stosunków własnościowych, społecznych i narodowościowych, osadnictwa, krajobrazu, gospodarki, kultury materialnej, życia codziennego, języka, heraldyki, genealogii, szkolnictwa i kultury umysłowej. Zawierają wiele informacji dotyczących patronimiki, przydomków i zawodów żydowskich mieszkańców Lublina, a także topograficznych opisów miejsc będących własnością i użytkowanych przez Żydów.

Niestety to, co jest ich dobrodziejstwem, jest zarazem problemem niemożliwym do rozwiązania dla pojedynczego badacza. Materiał zawarty w księgach sądowych pozwala na stawianie im niezliczonych pytań, jednak liczba tych źródeł oraz objętość skutecznie uniemożliwiają prowadzenie efektywnych badań ${ }^{\text {. }}$

W takich przypadkach rozwiązaniem jest agregacja danych w edycji bazodanowej, której możliwości indeksacyjne najlepiej służą do opracowania źródeł. Bazy danych wykorzystywane są do gromadzenia, przetwarzania i zapewnienia dostępności ogromnych ilości danych. Są narzędziami, które umożliwiają przeszukiwanie na pierwszy rzut oka nieistotnych danych, łączenie ich według zadanych kryteriów, gromadzenie w zbiorach danych i generowanie modeli statystycznych. Analiza dużych danych (big data) jest zaprojektowana tak, aby bez wysiłku wykorzystać zasoby, które są zasadniczo wysoce zróżnicowane, złożone i zazwyczaj słabo ustrukturyzowane. Składają się na nie dane analogowe - tekstowe i liczbowe.

Odpowiednio korzystając z danych źródłowych, stworzono taką cyfrową bazę; rozbudowano jej kryteria, aby maksymalnie wykorzystać dostępne źródło. Dlatego baza danych zawiera rekordy podzielone na różnorodne kategorie - od płci, religii, narodowości, pochodzenia danej osoby, wykonywanej profesji czy zajmowanego stanowiska, miejsca zamieszkania czy pobytu, aż do relacji rodzinnych i sąsiedzkich z innymi osobami z bazy (il. 1 kryteria bazy danych).

Celem niniejszego artykułu jest przybliżenie korzyści płynących z analizowania danych źródłowych przy wykorzystaniu edycji bazodanowych. Artykuł przybliża kilka przykładowych historii rodzin i charakterystycznych miejsc Podzamcza oraz grupuje dane statystyczne według wybranych kryteriów, m.in.

\footnotetext{
1 T. Związek, Wydawać, ale jak? Propozycja cyfrowej edycji staropolskich ksiag sądowych XV-XVIII wieku, [w:] Editiones sine fine, t. 1, red. K. Kopiński, W. Mrozowicz, J. Tandecki, Toruń 2017, s. 207-208.
} 
kierunku migracji i dynamiki napływu ludności oraz różnorodności rzemiosł i profesji pozyskanych z bazy danych.

Przedmiot rozważań związany jest tylko $\mathrm{z}$ informacjami pozyskanymi z analizy judaików dotyczących mieszkańców lubelskiego Podzamcza i pochodzących wyłącznie z ksiąg grodzkich lubelskich z lat 1633-1733. Rekonstrukcja wyraźnie rysujących się problemów społecznych nie należy do tematyki prezentowanego tekstu.

Opisywane poniżej komentarze przedstawiają wyłącznie studium konkretnych przypadków - dotyczą jednostkowych przykładów (osób, rodzin, miejsc) w ramach ilustrowanych zagadnień i nie stanowią ciągłej narracji dla całego Podzamcza.

Sam pomysł konwersji danych z materiałów źródłowych do dziejów Żydów w księgach grodzkich lubelskich $\mathrm{z}$ lat 1633-1733 do cyfrowej bazy powstał w $2015 \mathrm{r}$. z inicjatywy Ośrodka „Brama Grodzka - Teatr NN”. Projekt realizowany był wspólnie z pracownią Archeé - Badania i Nadzory Archeologiczne ${ }^{2}$. Punktem wyjścia do cyfrowej bazy danych była analiza edycji źródłowej serii publikacji, które powstały dzięki gruntownej kwerendzie judaików w księgach grodzkich lubelskich z XVI-XVIII w., przeprowadzonej przez prof. Henryka Gmiterka ${ }^{3}$. Kwerenda zaowocowała czterema tomami, w których opublikowano regestry obejmujące czasy panowania Zygmunta III Wazy (1587-1632), Władysława IV i Jana Kazimierza (1633-1669), Michała Korybuta Wiśniowieckiego i Jana III Sobieskiego (1669-1697) oraz Augusta II (1697-1733), dostępne w Archiwum Państwowym w Lublinie ${ }^{4}$. Opracowania obejmują regesty wszystkich spraw sądowych toczących się przed Sądem Grodzkim w Lublinie, dotyczących Żydów zarówno z Lublina, jaki i spoza miasta. Są to jednocześnie materiały źródłowe do badań nad funkcjonowaniem staropolskiego sądownictwa, samorządów różnych szczebli, systemu fiskalnego, kultury materialnej czy życia codziennego różnych warstw społeczeństwa regionu.

${ }^{2}$ W projekt zaangażowanych było kilka osób: Sylwia Sobiesiak-Zimny, Jacek Jeremicz, Rafał Niedźwiadek i autor niniejszego artykułu - Piotr Zimny.

3 Materiały źródłowe do dziejów Żydów w księgach grodzkich lubelskich z doby panowania Augusta II Sasa 1697-1733, oprac. H. Gmiterek, Lublin 2001 (dalej: Materiały źródłowe 1); Materiały źródłowe do dziejów Żydów w księgach grodzkich lubelskich z doby panowania Michała Korybuta Wiśniowieckiego i Jana III Sobieskiego 1669-1697, oprac. H. Gmiterek, Lublin 2003 (dalej: Materiały źródłowe 2); Materiały źródłowe do dziejów Żydów w księgach grodzkich lubelskich z doby panowania Władysława IV i Jana Kazimierza Wazów 1633-1669, oprac. H. Gmiterek, Lublin 2006 (dalej: Materiały źródłowe 3).

${ }^{4}$ Archiwum Państwowe w Lublinie (dalej: APL), Księgi grodzkie lubelskie 1517-1810. 
Cele postawione w projekcie obejmowały m.in. przeniesienie akt sądowych ksiąg grodzkich lubelskich $\mathrm{z}$ lat 1587-1733 do bazy danych oraz stworzenie modelu społeczności zawierającego powiązania rodzinne, zawody, miejsce zamieszkania, stosunki sąsiedzkie, płeć i wyznanie. Oczekiwanym rezultatem było zbudowanie bazy danych dawnych mieszkańców lubelskiego Podzamcza i ich siedzib, a następnie powiązanie ich z zapisami z XX w. i istniejącymi bazami Ośrodka „Brama Grodzka - Teatr NN”.

Wstępne efekty projektu zostały przedstawione przez autora niniejszego artykułu oraz Jacka Jeremicza z Ośrodka „Brama Grodzka - Teatr NN” w dniu 7 sierpnia 2018 r. w Warszawie podczas 38. Żydowskiej Konferencji Genealogicznej, organizowanej przez International Association of Jewish Genealogical Societies wraz z Muzeum POLIN i Żydowskim Instytutem Historycznym we współpracy z państwową siecią archiwalną ${ }^{6}$. Ramowe efekty projektu zostały również opublikowane w opracowaniu poświęconym historii dzielnic Lublina ${ }^{7}$ oraz zamieszczone na stronie Ośrodka „Brama Grodzka - Teatr NN”, gdzie są systematycznie aktualizowane i rozbudowywane ${ }^{8}$.

Dane wykorzystane w omawianej bazie pochodziły bezpośrednio z zapisek źródłowych, czyli zredagowanych materiałów źródłowych do dziejów Żydów w księgach grodzkich lubelskich $\mathrm{z}$ lat 1633-1733. Opierały się przeważnie na danych skarbowo-podatkowych, które na pierwszy rzut oka wnoszą jedynie mniej czy bardziej dokładne dane statystyczne, nie mówią zaś niczego - lub mówią niewiele - o życiu owych społeczności, organizacji gmin, zajęciach mieszkańców, troskach i kłopotach dnia codziennego, współżyciu z innymi grupami

5 Integralną częścią systemu jest historyczny system informacji przestrzennej (H-GIS), który w precyzyjny sposób mapuje, opisuje i pozwala zrozumieć przekształcenia przestrzenne, jakie zaszły na danym obszarze. Lokalizację dawnych ulic i parcel można porównać ze współczesną mapą bądź zdjęciem satelitarnym miasta, zestawiając warstwy z różnych okresów historycznych. W przypadku zmian nazw ulic oraz numeracji domów i działek istnieje możliwość szybkiej identyfikacji dawnego adresu. Dotychczas do bazy osób wprowadzono ponad 72000 rekordów, do bazy miejsc ponad 12 ooo rekordów (dane na 2020 r.).

${ }_{6}<$ http://www.teatrnn.pl/kalendarium/wydarzenia/osrodek-brama-grodzka-teatr-nn-na-38zydowskiej-konferencji-genealogicznej-grodzka-gate-nn-theatre-centre-at-the-38th-internatio/> [dostęp: 18.03.2018].

7 Zob. R. Niedźwiadek, J. Tkaczyk, Kalinowszczyzna, Ponikwoda, Czwartek. O średniowiecznym Czwartku, Kalinowszczyźnie i Ponikwodzie, [w:] Lublin. 7oo-lecie. Historia dzielnic, red. D. Szulc, H. Mącik, Lublin 2017, s. 20-22.

$8<$ http://www.teatrnn.pl/leksykon>; <http://teatrnn.pl/podzamcze> [dostęp: 18.03.2021]. 
narodowościowymi i religijnymi. Dopiero zestawienie większej ilości zapisek $\mathrm{w}$ cyfrowej bazie danych pozwala na generowanie modeli statystycznych.

\section{Baza danych}

Obraz wyłaniający się z edycji opracowanych ksiąg grodzkich byłby statyczny i nie pozwalałby na obserwowanie zmiennych gospodarczych, dynamiki osadnictwa czy dziejów poszczególnych rodzin, gdyby nie umiejętne połączenie danych ${ }^{9}$. Dlatego wszystkie dane zostały zgromadzone w bazie danych, dzięki której możliwe jest proste przetwarzanie, porządkowanie i prezentowanie dużych ilości informacji. Dopełnieniem bazy danych są opracowane z zebranych danych diagramy, które umożliwiają śledzenie interesujących treści na przygotowanych podkładach kartograficznych i porównywanie ich w szerszym kontekście.

Czytelnik musi mieć pełną świadomość uproszczeń, które zostały zastosowane, aby możliwe było udostępnienie zawartości źródeł sądowych i obrazowanie jej na mapach, w statystykach czy na wykresach.

Architektura przestrzenna bazy danych (il. 2 architektura przestrzenna bazy danych) podzielona została na tabelę krytyczną (tabela zapisek i dat) oraz tabele źródłowe (indeksowe), podzielone według poszczególnych kryteriów: osoba (imię, nazwisko, przydomek), cechy (płeć, religia), profesja (zawód), miejsce (zamieszkania czy pobytu), kierunek (imigracja), rodzina (powiązanie genealogiczne) i relacje sąsiedzkie (bezpośrednie z innymi osobami z bazy).

Strukturą nadrzędną jest tabela zapisek, która pełni funkcję rozbudowanego spisu treści, nadając bazie określoną strukturę. W każdej z tabel znajdują się unikatowe identyfikatory, pełniące zarazem funkcję podstawowego klucza tabeli (id_ nazwa). Pozwalają one na połączenie treści struktury razem ze zindeksowanymi obiektami w relacji jeden-do-wielu. Zabieg ten wyklucza jakąkolwiek redundancję danych. Orientację czasową zapewniają kolumny daty źródłowej zapiski. Odnotowanie datacji poszczególnych zapisek sądowych pozwala na zgromadzenie olbrzymiego zestawu danych, które mogą być podstawą analiz chronologicznych oraz historyczno-prawnych.

Drugi człon bazy - będący rdzeniem - to tabele indeksowe, które gromadzą całość indeksów (osobowych, geograficznych i rzeczowych) opracowanych w ramach przygotowanej edycji materiałów źródłowych do dziejów Żydów z ksiąg

\footnotetext{
9 Zob. T. Związek, op. cit., s. 202-226.
} 
grodzkich lubelskich z lat 1633-1733, połączonych unikalnymi kluczami razem ze sobą i z tabelą zapisek w relacji jeden-do-jednego i jeden-do-wielu.

Zaproponowany schemat może być dowolnie rozbudowywany i może w przyszłości posłużyć do bazodanowego wiązania informacji o osobach i miejscach $\mathrm{z}$ innymi istniejącymi lub mającymi powstać zestawami danych genealogicznych zgromadzonych w bazach danych Ośrodka „Brama Grodzka - Teatr NN”. Celem nadrzędnym jest zbudowanie bazy danych dawnych mieszkańców lubelskiego Podzamcza oraz powiązanie ich z zapisami z XX w. i istniejącymi bazami Ośrodka „Brama Grodzka - Teatr NN”.

Baza złożona jest z podstawowych kategorii, które łączą się i wzajemnie uzupełniają. Wszystkie osoby i miejsca (punkty adresowe) są potraktowane jako osobne rekordy i jako takie mają swoje własne identyfikatory, a jednocześnie stanowią część większej całości - jako element sieci wzajemnych powiązań. To samo dotyczy wydarzeń i wzmianek źródłowych. Wszystkie te elementy są następnie wykorzystywane w bardziej złożonych formach opisu, jak historie rodzin i miejsc, mapy tematyczne czy infografiki, które zostały pokazane w dalszej części artykułu.

Wracając do relacyjnej bazy danych, należy wspomnieć, że utworzono ją na podstawie analizy prawie 6000 zapisek (il. 3 rozkład ilościowy ID i zapisek). Prawdziwie benedyktyńska praca pozwoliła zapisać i usystematyzować ponad 11 ooo rekordów (ID), które odpowiadają z imienia lub też i nazwiska osobom wyszczególnionym w regestrach ${ }^{10}$. Zaznaczyć należy, że sporo kłopotów przysporzyła identyfikacja nazwisk (patronimików, kognomenów), różnice językowe w staropolskim, hebrajskim i jidysz oraz pisownia występujących przy imionach Żydów określników ich zawodów, które bardzo często funkcjonowały też - wobec niewykształconych jeszcze nazwisk - jako ich przydomki.

Naturalnie dalszym etapem analizy mogą być rozważania obejmujące rekonstrukcje wyraźnie określonych problemów społecznych, jednak na potrzeby artykułu ograniczono rozważania tylko do kilku przykładowych zagadnień, m.in. kierunków migracji i zmian dynamiki napływu ludności na Podzamcze, relacji przestrzennych i sąsiedzkich pomiędzy wybranymi osobami i konkretnymi miejscami w przestrzeni przedmieścia, historii własności nieruchomości, historii rodzin oraz różnorodności rzemiosł. Część z tych zagadnień została skrótowo

10 R. Niedźwiadek, J. Tkaczyk, Przeszłość Kalinowszczyzny i Ponikwody w świetle odkryć archeologicznych, [w:] Lublin. Historia dzielnic w 7oo. rocznice lokacji miasta, red. J. Chachaj, H. Mącik, D. Szulc, Lublin 2017, s. 334-337. 
zaprezentowana na załączonych ilustracjach, które obejmują ogromną ilość informacji. Sieć linii łączy każdą grupę ludzi. Linie pokazują powiązania rodzinne i sąsiedzkie, a także konkretną lub możliwą lokalizację albo miejsce zamieszkania wskazanej grupy (il. 4 klucz do relacji na diagramach). Każda z ilustracji zawiera kluczowe punkty w krajobrazie miasta żydowskiego, np. Wielką Synagogę, Bramę Grodzką czy ówcześnie istniejące ulice, np. Żydowską. Taka forma zestawienia danych pozwala uprawdopodobnić miejsca zamieszkania/pobytu ówczesnych właścicieli domów oraz lokalizacje budynków użyteczności publicznej.

Zapiski źródłowe wymieniają z imienia i nazwiska prawie 10 ooo mężczyzn i nieco ponad 1000 kobiet żyjących na Podzamczu w latach 1633-1733. W tym gronie większość stanowili wyznawcy judaizmu ${ }^{11}$ - 6175 osób, chrześcijanie i wyznawcy innych religii skupiali niespełna 5500 osób (il. 5 rozkład ilościowy i procentowy wg kryterium: Religia). Dla nieco ponad 5000 osób ustalona została wykonywana profesja (zawód). Wśród zawodów zapiski archiwalne odnotowują zarówno powszechne zajęcia: rzeźnik, sługa, złotnik, kupiec, arendarz, jak też przedstawicieli zawodów bardziej nobilitowanych, których wykonywanie wiązało się z posiadanym majątkiem lub wykształceniem - np. pełniący funkcje wojskowe: hetman, chorąży, kapitan i porucznik, piastujący urzędy: wojewoda, burmistrz, wójt, ławnik, rajca i podczaszy, osoby duchowne: mnich, przeor, prepozyt, proboszcz, rabin, starszy synagogi oraz medycy: doktor i chirurg.

$\mathrm{W}$ analizowanych dokumentach odnotowano również informacje o kierunkach migracji ludności na lubelskie Podzamcze. Jako przykłady skrajności wskażmy np. kierunek zachodni, gdzie oprócz przyjezdnych z Bełżyc lub Opola, na Podzamcze przybywały też osoby z Szydłowca, Krakowa, Wrocławia, a nawet Amsterdamu, Wiednia i Szkocji. Cechy i informacje przypisane poszczególnym mieszkańcom udało się połączyć i wyszukać ciekawe prawidłowości. Między innymi podjęto próbę ustalenia relacji rodzinnych i sąsiedzkich (zobacz klucz - il. 4). Połączenia rodzinne (małżeństwo, rodzicielstwo, rodzeństwo) udało się ustalić dla ponad 2000 osób - w tym dla ponad 500 Żydów z Podzamcza i ponad 230 lubelskich chrześcijan zamieszkujących Podzamcze. Natomiast relacje sąsiedzkie odnotowano dla ponad 230 osób - w tym dla ponad 130 Żydów i ponad 80 lubelskich chrześcijan (il. 6-7 przykład relacji rodzinnych i sąsiedzkich na ul. Żydowskiej).

Dla prawie 9000 przypadków ustalono miejsce zamieszkania, z czego połowę stanowiły punkty w rejonie Lublina. Lecz tu należy uczulić czytelników - danych tych nie podano w znanej nam obecnie formie, np. pan $X$ był zameldowany przy

\footnotetext{
11 Co jest efektem selekcji informacji ze źródła.
} 
ulicy $Y$ pod numerem $Z$. Numeracja posesji jest wynalazkiem dopiero XIX-wiecznym, wcześniej zapisywano to zupełnie inaczej - pan $X$ mieszkał obok pana $A$, którego dom stał naprzeciwko $B$ itd. Taka forma informacji utrudnia lub nawet uniemożliwia ustalenie konkretnego umiejscowienia w przestrzeni. Niemniej w wielu przypadkach podano dane natury ogólniejszej, sytuując domostwo obok budowli znanej z historycznej topografii (il. 8 rozkład ilościowy i procentowy wg kryterium: Miejsce).

Informacje przypisane poszczególnym mieszkańcom pozwoliły śledzić historię własności zarówno pewnych nieruchomości, od momentu ich powstania, jak również parceli, od momentu wydzielenia w miejskiej przestrzeni. Pozwoliły również stworzyć statystycznie ujęty model społeczności, rozbity wg kryteriów: ID, płeć, religia, profesja, miejsce zamieszkania, relacje rodzinne i sąsiedzkie (il. 9 rozkład ilościowy i procentowy wg kryterium: Powiązania rodzinne; il. 10 rozkład ilościowy i procentowy wg kryterium: Relacje sąsiedzkie). Łącząc te relacje z opisami lokalizacji pewnych nieruchomości, stworzono mapę zasiedlenia historycznego Podzamcza. Efektem jest prawdopodobne rozmieszczenie wybranych osób na terenie miasta żydowskiego. Wyniki zostały zaprezentowane na przedstawionych niżej ilustracjach.

Na tej podstawie spróbowano ustalić konkretne relacje przestrzenne i określono miejsce pobytu w Lublinie i na Podzamczu dla prawie 3200 Żydów i prawie 1500 chrześcijan. Na przykład zapisano, że Tobiasz Percowicz mieszkał przy łaźni miejskiej, zaś obok niego stał dom Lewka Baryły. Zabudowania tego samego Lewka Baryły przylegały do Bramy Grodzkiej, a po jednej jego stronie żyła Cyria Ickowiczowa z mężem Ickiem Berkowiczem Czarnym, a po drugiej - Eliasz Izraelowicz (il. 11 rodzinne relacje i sąsiedzkie powiązania w pobliżu Bramy Grodzkiej).

Dokładna lokalizacja poszczególnych kamienic, wraz z charakterystycznymi punktami znajdującymi się w ich pobliżu (tj. Brama Grodzka, łaźnia, szkoła synagogi żydowskiej itp.), pozwala na odtworzenie prawdopodobnej lokalizacji konkretnych budynków wraz z ich właścicielami. Schemat z obrazem pożaru Lublina z 1719 r. sugestywnie ilustruje ten socjotopograficzny aspekt bazy danych mieszkańców lubelskiego Podzamcza.

Zapewne i ta próba rekonstrukcji obrazu Podzamcza w okresie staropolskim zawiera wiele ograniczeń i niedokładności płynących wprost z wykorzystanych źródeł. W tym kontekście podjęty wysiłek można zaklasyfikować do badań z pogranicza archiwistyki, historii i socjologii. Odsłanianie i interpretowanie źródeł, a przez co identyfikacja zdarzeń jednostkowych służyć mogą odtworzeniu historii miejsc i ludzi. 
Wizualizację relacji można uznać za udany rezultat przedstawienia „surowych danych" w przystępnej formie. Spojrzenie takie nie jest oczywiście pozbawione wad. Obarczone jest ograniczeniami wynikającymi z nieścisłości opisu lokalizacji nieruchomości, a także wąskimi ramami chronologicznymi i jednostronnością użytych źródeł. Należy mieć pewność, że nie wszystkich mieszkańców tej części miasta odnotowano na kartach dokumentów, dla większości z nich nie dysponujemy pełnym zasobem danych. Niemniej jednak uzyskany efekt uznać trzeba za zadowalający, tym bardziej że jest on tylko wstępem do dalszych badań, ukazującym metodę i możliwości. W efekcie końcowym planowane jest zbudowanie pełnej bazy danych wiążącej dawnych mieszkańców Podzamcza i ich siedzib z zapisami sporządzonymi w XX w., gdy odnotowywano już numery posesji.

\section{Wizualizacje}

Główny akcent $\mathrm{w}$ prezentowanym artykule położony jest na zastosowanie baz danych do opracowania i analizowania badanych źródeł. Ilustracją tego typu możliwości jest kilka poniższych przykładów obejmujących wybrane kryteria - m.in. kierunek migracji i dynamikę napływu ludności na Podzamcze, relacje przestrzenne i sąsiedzkie pomiędzy poszczególnymi osobami i konkretnymi miejscami w przestrzeni podzameckiego przedmieścia. Na podstawie kilku przykładów przybliżone zostaną historie wybranych nieruchomości oraz kilku rodzin wraz z ich drzewami genealogicznymi, a także różnorodność rzemiosł i profesji.

Przykładowe zagadnienia należy umieścić na lekko zarysowanym tle historycznym. Warto przypomnieć, że historia Podzamcza nierozerwalnie połączona była ze wzgórzem zamkowym i staromiejskim „miastem w murach”. Dopiero 15 lipca 1595 r. Podzamcze otrzymało prawny dokument, w którym król nadał przywilej lokacji ${ }^{12}$ na prawie magdeburskim z własnym wójtem, magistratem, ławnikiem i cechami rzemieślniczymi, w skład których wchodzili zarówno rzemieślnicy chrześcijańscy, jak i żydowscy ${ }^{13}$. Granice Podzamcza - przedmiejskiej dzielnicy, na północy sięgały do wzgórza Czwartek, na zachodzie do stawu na rzece Czechówce, zwanego „za Żydy” lub „Żydowskim”. Na wschodzie Podzamcze

\footnotetext{
12.11.2020].

$12<$ http://lac.lublin.pl/dokumenty/xvi-wiek/1576-1597/1595-15-lipca-krakow/> [dostęp:

${ }_{13}$ B. Mark, Rzemieślnicy żydowscy w Polsce feudalnej, „Biuletyn Żydowskiego Instytutu Historycznego" 1954, nr 11-12, s. 74, 78; Riabinin J., Materiały do historii miasta Lublina 1317-1792, Lublin 1938, s. 19.
} 
dochodziło do klasztoru oo. Bazylianów (obecnie cerkiew prawosławna) i wzgórza Grodzisko, choć w niektórych źródłach jurydyka miała obejmować swym zasięgiem Słomiany Rynek ${ }^{14}$. Podzamcze w przeważającej części położone było $\mathrm{w}$ dolinie rzeki Czechówki. Stopniowe osuszanie doliny pozwoliło na rozwój osadnictwa, które zostało przekazane pod zarząd starosty grodowego, a to z kolei doprowadziło do utworzenia jurydyki królewskiej ${ }^{15}$.

Na kilka słów uwagi zasługuje również baza kartograficzna. W przypadku Podzamcza zmiany, które zaszły na przestrzeni stuleci, ze względu na brak planów miejskich właściwie uniemożliwiają pełną rekonstrukcję topografii przed końcem XVIII w. Najwcześniejszym odzwierciedleniem, które odnosi się do omawianego obszaru, jest widok Lublina stworzony przez Brauna i Hogenberga z 1618 r. ${ }^{16}$ (il. 12 Podzamcze), a także obraz Pożar miasta Lublina (powstały między 1720 a 1752 r.) ${ }^{17}$. Dopiero mapa Lublina autorstwa Feliksa Bieczyńskiego, która jest kopią planu Stanisława Jana Łęckiego z 1783 r., ukazuje wewnętrzne rozplanowanie Podzamcza ${ }^{18}$. Obraz kartograficzny jurydyki podzameckiej w Lublinie dopełnia w niniejszym artykule plan E. Rennera sprzed 1800 r. $^{19}$ (zobacz: il. 20-25). Wspomniane plany są podstawą utworzonych infografik.

Przechodząc do ilustrowania poszczególnych zagadnień, rozpocząć należy od kierunków migracji i dynamiki napływu ludności na Podzamcze. Na potrzeby projektu stworzono schemat zmian ilości wpisów źródłowych z poszczególnych lat, który w razie potrzeby można uszczegółowić o dynamikę w poszczególnych miesiącach $\mathrm{z}$ analizowanego okresu (il. 13 dynamika zmian ilości zapisek).

Oczywisty jest fakt, że głównym czynnikiem napływu ludności był rozwój handlu. Żydzi pełnili różne role w polskim społeczeństwie, jednak najbardziej

14 S. Wojciechowski, Gmina żydowska w Lublinie w XVI wieku, „Biuletyn Żydowskiego Instytutu Historycznego" 1952, nr 2, s. 204-230.

15 Cała historia Podzamcza opowiedziana została w artykule Jacka Jeremicza, Ośrodek „Brama Grodzka - Teatr NN”, <http://www.teatrnn.pl/leksykon/artykuly/podzamcze-jako-jurydyka/> [dostęp: 12.11.2020].

16 Wojewódzka Biblioteka Publiczna im. H. Łopacińskiego w Lublinie: J. Braun i A. Hogenberg, Theatrum praecipuarum totius mundi urbiurti (Przedstawienie wyróżniających się miast całego świata), znane pod nazwą Civitates orbis terrarum, Kolonia 1618, 10-IV.B.

17 Obraz znajduje się w bocznej kaplicy Bazyliki oo. Dominikanów w Lublinie.

18 APL, Akta miasta Lublina, Plany miasta Lublina, sygn. 3. Mapa Lublina autorstwa Feliksa Bieczyńskiego jest kopią planu Stanisława Jana Łęckiego z 1783 r.

19 Plan miasta Lublina - E. Renner (ok. 180o), Aufnahmsblatt der Stadt Lublin aufgenommen vom Oberlieut. Renner des Franz Jellachichischen Inft. Rgts, MS.-Glk61, Kriegsarchiv, Wien. 
kojarzeni są właśnie $\mathrm{z}$ handlem ${ }^{20}$. Aktywność na tym polu miała wpływ na ich mobilność tak na rynku lokalnym, gdy reprezentowali własne interesy, jak i w kontaktach międzynarodowych, gdy działali w imieniu magnaterii, a nawet samego króla Polski.

Lublin przyciągał jak magnes ludzi z każdej strony świata. Pełnił ważną rolę jako miasto jarmarków, centrum wymiany towarowej. Tradycyjnie był miejscem krzyżowania się ważnych szlaków handlowych (il. 14 kierunki napływu ludności do Lublina w latach 1633-1733). Jarmarki, organizowane 4-6 razy w roku, na podstawie specjalnych przywilejów stwarzały szczególnie sprzyjające warunki do wymiany kulturalnej i generowały wyjątkowy klimat kulturalny. W czasie wielkich targów i jarmarków rozwijał się nie tylko obrót towarowo-kredytowy, lecz także handel książkami, mapami, obrazami, różnymi obiektami służącymi rozrywce i związanymi z kultem (szachy, karty do gry, kości, różańce, krzyżyki, obrazy święte), o czym świadczą także wyniki badań archeologicznych ${ }^{21}$.

Kolejnym czynnikiem determinującym napływ ludności była migracja związana z uniknięciem bezpośredniego zagrożenia. Podczas burzliwych czasów aktywność handlowa przygasała. Na terenach objętych wojną nasilały się natomiast ruchy ludności. Wojny kozackie i potop szwedzki pociągnęły za sobą nędzę i poczucie stałego zagrożenia wśród ludności wschodniej części Rzeczypospolitej. Sprzyjało to radykalizacji postaw. Ludność żydowska odchodziła od ortodoksji. Wzrosło natomiast zainteresowanie mistyką. Pojawił się chasydyzm. Ze względu na swoje tradycje i znaczenie dla ultraortodoksyjnych chasydów Lublin zyskał określenie „Chasydzka Jerozolima".

Liczba osób różnych wyznań przybywających do Lublina zmieniała się w poszczególnych okresach. $Z$ analizy danych wynika, że w latach 1633-1669, w dobie panowania Władysława IV i Jana Kazimierza Wazów, wynosiła 858 osób, w latach 1669-1697 - podczas panowania Michała Korybuta Wiśniowieckiego i Jana III Sobieskiego do Lublina przybyło 1845 osób, natomiast największa fala migracji do miasta miała miejsce za panowania króla Augusta II Sasa - w latach 1697-1733 - kiedy pojawiło się 1991 przybyszów. Dominującą grupę przybyszów stanowili Żydzi² ${ }^{22}$. Stwarzało

20 J. Jeremicz, P. Zimny, <http://www.teatrnn.pl/leksykon/artykuly/naplyw-ludnosci-do-lublina-w-latach-1633-1733> [dostęp: 18.01.2021].

21 P. Zimny, Fosa średniowiecznego Lublina i jej otoczenie w świetle badań interdyscyplinarnych, [w:] Krakowskie Przedmieście w 45o-lecie Unii Lubelskiej, red. R. Niedźwiadek, Lublin 2019, s. $201-228$.

22 J. Jeremicz, P. Zimny, <http://www.teatrnn.pl/leksykon/artykuly/naplyw-ludnosci-do-lublina-w-latach-1633-1733> [dostęp: 18.01.2021]. 
to specyficzne, szczególnie sprzyjające rozwojowi kultury warunki ze względu na silną koncentrację na jego terenie twórczego potencjału ludzkiego i ekonomicznego.

Biorąc pod uwagę kierunki świata, na pierwszym miejscu należy wymienić najbliższe sąsiedztwo Lublina. Kierunkiem, z którego najczęściej przybywali podróżni na Podzamcze w latach 1633-1733, był południowy wschód, skąd łącznie dotarły 1493 osoby. Należy zwrócić uwagę na oddaloną o zaledwie $30 \mathrm{~km}$ Łęczną - z niej do miasta przybyło łącznie 130 osób, w tym 110 Żydów. W księgach grodzkich odnotowana jest dość duża liczba przedstawicieli Biłgoraja, Kraśnika czy Modliborzyc oraz przybyszy z miejscowości takich, jak Turobin czy Tarnogród. Dość licznie reprezentowani byli mieszkańcy Kazimierza nad Wisłą, którzy przybyli do Lublina w liczbie 34, w tym 12 Żydów, oraz z Bełżyc - 31 osób, z czego 16 było Żydami. Pojawiły się też osoby z innych miasteczek Lubelszczyzny, m.in. z Łukowa, Kocka czy Radzynia.

Podczas panowania Władysława IV (1632-1648) i Jana Kazimierza (1648-1668) najwięcej osób dotarło do miasta z miejscowości najbliższych Lublinowi, np. Kazimierza nad Wisłą. Za panowania Michała Korybuta Wiśniowieckiego (1669-1673) i Jana III Sobieskiego (1674-1696) wśród przybyłych dominowali mieszkańcy Łęcznej -130 osób. W czasie rządów Augusta II Sasa (1697-1706 i 1709-1733) oraz Stanisława Leszczyńskiego (1704-1709) najwięcej osób przybyło z Łucka. Wyraźnie zarysowało się też kilka ważnych kierunków związanych z handlem dalekosiężnym - np. Gdańsk na północy czy Kraków na południowym wschodzie, Kijów, Lwów (Ukraina) i Włodzimierz (Rosja) na wschodzie oraz Grodno i Wilno (Litwa) na północnym wschodzie.

Za panowania Michała Korybuta Wiśniowieckiego i Jana III Sobieskiego do Lublina podróżowała ludność z krajów bardzo dalekich, czasem odległych nawet o ponad tysiąc kilometrów. Wymienić trzeba także szczególnie licznych podróżnych przybywających z południowego wschodu. W księgach grodzkich można odnaleźć mieszkańców Bracławia, którzy musieli przebyć ponad $600 \mathrm{~km}$, a także z Kijowa, Lwowa, Ostrowa, Łucka czy Mohylowa Podolskiego. Odległość ponad $500 \mathrm{~km} \mathrm{z} \mathrm{leżącego} \mathrm{na} \mathrm{północnym} \mathrm{zachodzie} \mathrm{Gdańska} \mathrm{pokonały} 23$ osoby, w tym 16 Żydów. 7 osób przybyło z odleglejszych stron, np. z oddalonego o ponad $300 \mathrm{~km}$ Grodna, z położonego $270 \mathrm{~km}$ dalej Nowogrodu czy oddalonego o $160 \mathrm{~km}$ Drohiczyna. Z położonego w odległości około $200 \mathrm{~km}$ Przemyśla do miasta przybyły 22 osoby wyznające różną wiarę.

Przybysze docierali do miasta z najodleglejszych zakątków Europy. Opracowane źródło wskazuje, że przybywano z terenów obecnej Austrii, Czech, Inflant, 
Niderlandów, Litwy, Rosji, Szkocji ${ }^{23}$, Szwecji i ziem ukraińskich w granicach Rzeczypospolitej. Spośród przybyłych na lubelskie Podzamcze w bazie danych odnotowano np. obecność osób ze Szwecji - oficer Stenbock; ze Szkocji - Styffen Wilhelm; z Amsterdamu - kupcy Baltazar i Falk Amsterdamczyk; z Wiednia - złotnik Mojżesz Jakubowicz, z Salzburga - Eliasz Valerstain Rabin; z Pragi i Moraw - seniorzy gminy Chaim Dawidowicz Cukiernik czy też Jakub z Pragi; a także Żyda przybyłego z inflanckiej Parnawy.

Za panowania Augusta II Sasa oraz Stanisława Leszczyńskiego do miasta migrowali ludzie $\mathrm{z}$ różnych stron świata. Z północnego zachodu, w liczbie powyżej 10 osób, do miasta przybyły z oddalonej o ponad $400 \mathrm{~km}$ Bydgoszczy 33 osoby, a z położonego o ponad $100 \mathrm{~km}$ Łętowa - 22 osoby, z których połowę stanowili Żydzi. Rzadziej napływali do Lublina mieszkańcy ziem zachodnich: ich liczba, z wyjątkiem Pińczowa, z którego przybyło 7 osób, nie przekroczyła 5. Biłgoraj, Biskupice i Szczebrzeszyn to miejscowości położone na południe od Lublina, z których również odnotowano napływ ludności. Dość dużo osób dotarło z południowego zachodu, np. z Krakowa (12 Żydów i 18 chrześcijan). Do Lublina $\mathrm{z}$ północnego wschodu wędrowała ludność $\mathrm{z}$ takich miast, jak Lewartów (obecnie Lubartów), Parczew, Rawa oraz Brześć. Z tego kierunku dotarło również 5 Żydów i 8 chrześcijan z Wilna.

Identyfikacja wyznania $\mathrm{z}$ narodowością prowadziły do istnienia w miastach odrębnych cechów rzemieślniczych. Większość Żydów zajmowała się rzemiosłem: wytwórczością tekstylną (przędzalnictwem, tkactwem i zbytem odzieży na wsi), skórzaną, spożywczą (w tym gorzelnictwem), metalurgiczną. W miastach i miasteczkach świadczyli usługi aptekarskie, lekarskie, złotnicze itp. ${ }^{24}$

Od 1616 r. w Lublinie wyznawanie religii katolickiej było warunkiem wstępu do większości cechów, podczas gdy w latach wcześniejszych panowała większa tolerancja i Żydzi mogli należeć np. do cechów krawieckich czy szewskich. W 1616 r. w wielu cechach lubelskich podkreślano, że warunkiem przynależności jest wyznawanie katolicyzmu (bednarze, kołodzieje, stelmachowie, powroźnicy), powtórzono to w 1650 r. Konieczność bycia katolikiem wprowadziły również oficjalnie cechy mieczników (1618), kotlarzy i cieśli (1619), konwisarzy (1620), piwowarów (1649), chirurgów (1661). Jedynie cech złotników nie opowiedział się

${ }^{23}$ Więcej o tym zagadnieniu zob. A. Krawczyk, Szkoci w Lublinie i Lubelskim w XVII wieku, „Rocznik Lubelski”, t. 35, 2009, s. 77-86.

24 M. Bogucka, op. cit., s. 42-48. 
za dyskryminacją i jego członkami byli różnowiercy. Sytuacja grekokatolików na Lubelszczyźnie była zróżnicowana. W niektórych miastach byli do cechów dopuszczani (np. Tomaszów). W zachodniej Małopolsce wygasanie reformacji i rozwój kontrreformacji w miastach prowadził do zmian w polityce cechowej ${ }^{25}$.

Liczba różnych przedstawicieli gmin żydowskich i wykonywanych profesji pokazuje nasilenie osadnictwa i rozwój tej społeczności. O ile w dziedzinach tradycyjnie związanych $\mathrm{z}$ handlem towarami i obrotem pieniędzmi dominowali Żydzi, o tyle w kategorii właścicieli i mieszczan wyróżniali się głównie chrześcijanie.

W lubelskich księgach grodzkich znajdują się informacje na temat profesji, jakimi trudnili się ludzie w nich odnotowani. Dzięki tym opisom można częściowo odtworzyć listę zawodów występujących w latach 1633-1733 w Lublinie (il. 15-16. rozkład ilościowy i procentowy wg kryterium: Profesja). Przedstawione dane pochodzą z 6983 wzmianek o profesjach. Lubelska społeczność żydowska w połowie XVII w. stanowiła duży procent ogółu mieszkańców. Lubelskie Podzamcze tworzyło dla Żydów ważne centrum osadnictwa i siłą rzeczy reprezentowane było przez ludzi trudniących się różnymi zawodami i profesjami ${ }^{26}$.

W sprawach związanych ze społecznością żydowską najczęściej wzmiankowane są rozmaite funkcje religijne. Odnotowano ich łącznie $1759 \mathrm{w}$ ciągu wspomnianych stu lat. Księgi grodzkie z każdego z trzech podokresów (lata 1633-1669, 1669-1697 i 1697-1733) zawierały więcej informacji o żydowskich niż chrześcijańskich osobach pełniących funkcje religijne. W całym stuleciu były zaledwie 273 przypadki dotyczące chrześcijańskich osób duchownych. Miało to zapewne związek z faktem, że religijni przedstawiciele lubelskiej gminy żydowskiej byli często jej reprezentantami w kontaktach z nieżydowskimi instytucjami i osobami.

Drugą najliczniejszą kategorią zawodów występujących w księgach grodzkich byli urzędnicy. W tym przypadku sytuacja wyznaniowa przedstawia się jednak inaczej: w zapiskach pojawiło się więcej urzędników chrześcijańskich niż żydowskich. Warto zauważyć, że ich liczba zwiększała się w poszczególnych trzech podokresach czasowych.

$\mathrm{Na}$ tle reszty społeczeństwa Żydzi dominują w dziedzinach tradycyjnie związanych $\mathrm{z}$ handlem towarami i obrotem pieniędzmi. W księgach grodzkich

25 Ibidem.

26 J. Jeremicz, P. Zimny, <http:/www./teatrnn.pl/leksykon/artykuly/zawody-wymieniane-w-ksiegach-grodzkich-w-latach-1633-1733/> [dostęp: 18.01.2021]. 
z lat 1633-1733 pojawiły się 1054 informacje o kupcach. W latach 1633-1669 więcej było wiadomości o kupcach chrześcijańskich. Jednak w kolejnym przedziale czasowym, obejmującym lata 1669-1697, prym wiedli kupcy żydowscy, którzy byli wzmiankowani 120 razy. Ta przewaga uległa zwiększeniu w ostatnim przedziale czasowym, przypadającym na lata 1697-1733. Podczas rozwoju Podzamcza na początku XVII w. udział kupców żydowskich był jeszcze niewielki, natomiast na początku XVIII w. przewyższał już liczbę polskich kupców.

Kolejną grupą zawodową dość licznie reprezentowaną w księgach grodzkich byli właściciele nieruchomości, w tym mieszczanie lubelscy. Pojawili się oni w aktach grodzkich 815 razy. W tej kategorii przez całe stulecie niepodzielnie ilościowo przeważały informacje o właścicielach chrześcijańskich.

Interesująco rysuje się także ilość arend pod kątem liczebności wpisów wszelkiego rodzaju: dóbr, browarów, karczem, młynów, prowentów, podatków itp., czyli osób zarządzających mieniem powierzonym im przez właściciela. Kwestii arend dotyczy niemal 1/4 ogółu wpisów, a Żydzi wyraźnie mają przewagę $\mathrm{w}$ tej profesji. Również liczba ekonomów rosła wraz z czasem. O ile w latach w latach 1633-1669 ta kategoria została wymieniona 75 razy w księgach grodzkich, o tyle w drugiej połowie XVII w. pojawiła się już 305 razy, z czego w 284 przypadkach odnosi się do Żydów. W latach 1697-1733 zauważalny jest wzrost informacji o chrześcijańskich arendarzach i ekonomach, którzy jednak nie występowali w księgach grodzkich tak często jak ich żydowscy odpowiednicy.

W zawodach związanych z medycyną obserwujemy niewielką przewagę Żydów. Byli wymieniani jako doktorzy medycyny, chirurdzy i aptekarze. W latach 1633-1733 pojawili się w księgach grodzkich 86 razy. Żydzi stanowili większość w każdym z trzech podokresów. Liczba medyków wzrastała z czasem. Tak samo rysuje się sytuacja w profesji złotnika i jubilera, o których z rzadka można znaleźć informacje w księgach grodzkich. $\mathrm{Z}_{42}$ informacji odnoszących się do całego stulecia 6 przypada na czas pomiędzy 1633 a 1669 r. Liczba złotników rosła wraz z czasem, a już od drugiej połowy XVII w. żydowskich fachowców było więcej niż chrześcijańskich. Taki stan utrzymywał się również na początku XVIII w.

Chociaż wspólnota żydowska była skonsolidowana z resztą społeczeństwa, to była prawie w ogóle nieobecna w dziedzinie wojskowości, a jej przedstawiciele nie zajmowali wysokich stanowisk w urzędach państwowych. Wojskowi byli wzmiankowani 272 razy w księgach grodzkich, z czego w ogromnej większości były to informacje dotyczące wojskowych chrześcijańskich. Przez całe stulecie wspomniano zaledwie o 6 żydowskich żołnierzach. Liczba wojskowych rosła 
przez całe stulecie, począwszy od liczby 50, a swoją najwyższą wartość osiągnęła w latach 1697-1733, dochodząc do liczby 145.

Prawnie zakazane, choć nieprzestrzegane, posiadanie żydowskiego służącego czy „famulusa” widoczne jest w analizie zapisek. Także Żydzi, w niewielkiej liczbie, posiadali chrześcijańskich służących. Proceder ten był na początku akceptowany, lecz już w połowie XVII w. zaczął być piętnowany przez gorliwe władze kościelne i niektórych starostów miejskich. Słudzy byli ciekawą kategorią zawodową. Przez całe stulecie pojawiły się informacje o 173 sługach w księgach grodzkich, dotyczące jednocześnie Żydów i chrześcijan. Częściej w tych zapisach byli wymieniani słudzy chrześcijańscy. Ich liczba stopniowo rosła, by zmniejszyć się na początku XVIII w. Grupa służących żydowskich nie przekroczyła 6 osób. Posiadanie sług chrześcijańskich przez Żydów było zakazane, a informacje o tym prawie można odnaleźć już w 1608 r. Groziła za to kara grzywny. Taki stan rzeczy potwierdzają informacje z ksiąg grodzkich, w których słudzy występują głównie jako przedstawiciele chrześcijańskich panów.

Żydowscy przedstawiciele szeroko rozumianego rzemiosła zrzeszeni byli w cechach (np. garbarskim, szewskim, krawieckim, rzeźniczym), które konkurowały z innymi grupami społeczności miejskiej, w tym z cechami lubelskimi. W tym ostatnim przypadku spory dotyczyły najczęściej niewywiązywania się Żydów z umów dotyczących corocznych opłat na rzecz cechów. Znacznie mniej licznie reprezentowane były grupy zawodów wyspecjalizowanych, takich jak: bednarze, kurdybannicy, kuśnierze, introligatorzy, kołodzieje, woźnice, młynarze, muzycy, murarze, piekarze, powroźnicy, propinatorzy alkoholi, zarządcy mennicy, szyprowie, tragarze i żupnicy ${ }^{27}$. Rzemieślnicy pojawili się w księgach grodzkich 308 razy. Początkowo więcej informacji było o rzemieślnikach chrześcijańskich niż żydowskich. Sytuacja odwróciła się w okresie w okresie 1669-1697 i trwała do 1733 r. Warto zauważyć, że na drugą połowę XVII w. przypadało najwięcej wzmianek o rzemieślnikach.

Cechy nie prowadziły jedynie działalności związanej z produkcją, ale organizowały też dla swych członków życie kulturalne i towarzyskie oraz - jak już wspomniano - religijne (wspólny udział w obrzędach, takich jak pogrzeby i śluby, uczestnictwo w procesjach i nabożeństwach). Istnienie osobnych cechów etniczno-wyznaniowych z jednej strony umacniało identyfikację

27 M. Bogucka, op. cit., s. 52-55. 
poszczególnych grup, z drugiej - utrudniało zbliżenie z innymi grupami, mimo że były pokrewne zawodowo, a więc łączył je podobny sposób życia i status majątkowy ${ }^{28}$.

Nierzadko do ksiąg grodzkich trafiały sprawy sporne między samymi Żydami, dotyczące organizacji ich samorządu, rywalizacji personalnej, toczącej się w obrębie gminy walki między różnymi koteriami. W serii zapisów dominują wpisy pokwitowań spłaty długów i dotyczące wypełniania zobowiązań finansowych pomiędzy Żydami lub Żydami a przedstawicielami innych społeczności, ale są też kontrakty dzierżawne, zastawne, zapisy różnych sum na wyderkaf, akty kupna-sprzedaży nieruchomości (nawet te dokonywane przed sądem żydowskim były często oblatowane w grodzie), akty intromisji czy tradycji.

Najliczniejszą grupę wpisów w opracowanych źródłach stanowią sprawy wszelkiego rodzaju rozliczeń finansowych: długów, zastawów, wyderkafów, zaciąganego kredytu, operacji handlowych, kontraktów dzierżawnych. Pokazują one skalę powiązań gospodarczych między Żydami a szlachtą oraz mieszczaństwem, jak również między ośrodkami. Pamiętać jednak należy o tym, że są to akta sądowe, które ze swej natury uwypuklają raczej konflikty społeczne niż przypadki współpracy, dlatego byłoby niewłaściwe przedstawienie omawianego materiału jako dokładnego odbicia rzeczywistości społecznej ${ }^{29}$.

Do najpowszechniejszych form kontaktu między Żydami i szlachtą, wyłaniających się wyłącznie z ksiąg grodzkich lubelskich, należy udzielanie pożyczek Żydom. Były rodzajem inwestycji dokonywanych przez szlachtę w sferze działań gospodarczych. Zastaw w takich przypadkach stanowiły bardzo często nieruchomości. Pożyczki były przez Żydów chętnie przyjmowane, czasami mogły mieć jednak niefortunne konsekwencje. Jeśli żydowski dłużnik nie był w stanie spłacić długu szlachcicowi, jego dom w żydowskiej dzielnicy miasta mógł przejść w ręce nieżydowskie. Były nawet przypadki, kiedy sami szlacheccy wierzyciele zamierzali się wprowadzić do tak uzyskanej nieruchomości ${ }^{30}$.

Jednym $\mathrm{z}$ takich przykładów jest historia rodziny Marka Kamienieckiego $^{31}$ i powiązane $\mathrm{z}$ nią historie kilku kamienic. Icek Łazarowicz, syn zmarłego Łazarza Jewłowicza, był właścicielem kamienicy przy ul. Żydowskiej

\footnotetext{
28 Ibidem.

29 Materiały źródłowe 2, s. 99 nn.

30 Ibidem.

31 <http://www.teatrnn.pl/ludzie/osoby/id/Iooo15840/> [dostęp: 3.02.2021].
} 
(il. 17 rodzina Marka Kamienieckiego). W 1663 r. sąd nałożył na niego karę infamii za przywłaszczenie sobie różnych złotych i srebrnych rzeczy, oddanych niegdyś jego ojcu pod zastaw przez małżeństwo Nehrebeckich. 14 czerwca $1678 \mathrm{r}$. prawo do kamienicy Łazarowicza sąd przyznał spadkobiercy Nehrebeckich Mikołajowi Zabokrzyckiemu. Pomimo protestów rodziny Łazarowicza, Zabokrzycki został wprowadzony w posiadanie placu na lubelskim Podzamczu ${ }^{32}$. Kamienicę zwano „Łazarowiczową ${ }^{\text {33 }}$. Kolejny wpis źródłowy z 19 sierpnia 1689 r. odnosi się do Icka Dawidowicza, dziedzica kamienicy zwanej „Łazarowską”, dla której zanotowano, że położona była przy ul. Żydowskiej, pomiędzy kamienicami Eliasza Semenowicza i Moszka Jeleniowicza. Icek był synem Dawida Łazarowicza i Frejdy Wulfowiczowej oraz mężem Małki Izraelowej. Icek poprzez donację przekazał swoją część kamienicy - wraz ze znajdującym tam sklepem małżeństwu: Markowi Irszowiczowi i Drezli Szmulowiczównej ${ }^{34}$.

Dnia 25 czerwca 1691 r. Pejsak Kantorowicz Nisanowicz swoją część kamienicy zwanej „Doktorowską” wraz ze sklepem, która położona była przy ul. Żydowskiej, obok kamienicy Józefa Doktorowicza, oddał drogą donacji kupcowi lubelskiemu Perecowi Markowi Kamienieckiemu ${ }^{35}$, synowi Marka Kamienieckiego. Po dwóch tygodniach kupiec Perec Marek wprowadził się do kamienicy ${ }^{36}$. Józefa Doktorowicza znamy również z zapiski datowanej na rok 1691, gdzie wskazywany był jako dzierżawca różnych podatków. Był synem Jelenia Doktorowi$\mathrm{cza}^{37}$. Jeleń - senior gminy lubelskiej i poborca publicznego podatku zwanego „furmanką" - pierwszy raz pojawił się w naszych źródłach w roku $1633^{38}$. Kilka lat później złożył protest sądowy przeciwko wdowie i synowi jego dłużnika Krystynie Wołowiczównie i Gabrielowi Kierle ${ }^{39}$. Dnia 15 maja 1636 r. trybunał sądowy w Radomiu pozwał Jelenia o przywłaszczenie i niewpłacenie do skarbca publicznego dwu sum pochodzących z podatków - 4475 złp i 1000 złp ${ }^{40}$. Jednak najbardziej znacząca zapiska odnosząca się do Jelenia była datowana na 1634 r. wówczas został oblatowany przywilej polskiego króla Władysława IV Wazy, który

\footnotetext{
32 Materiały źródłowe 2, s. 100, nr 548.

33 <http://www.teatrnn.pl/ludzie/osoby/id/Iooo15840/> [dostęp: 3.02.2021].

34 Ibidem, s. 221-222, nr 1343.

35 Ibidem, s. 262, nr 1599.

36 Ibidem, s. 263, nr 1607.

37 Materiały źródłowe 3, s. 35, 39, nr 136, 167.

38 Ibidem, s. 22, nr 55.

39 Ibidem, s. 41, nr 178.

40 Ibidem, s. 44, nr 199.
} 
potwierdził zgodę starosty lubelskiego Mikołaja Firleja na zbudowanie murowanych bram w „Mieście Żydowskim”. Pierwsza z nich miała stanąć „pod Żórawiem, od rogu kamienicy Jelenia Doktorowicza do rogu domu Żydówki Danielki”. Druga brama miała stanąć „na Dyskim Gościńcu, od domu Józwa Kalmanowicza do domu Kopla Szmerlowicza”. Trzecia brama miała powstać „na Gościńcu Podzameckim, od muru Cerkwii do domu Żyda Dawida" ${ }^{41}$. Tak dokładne dane opisowe nie tylko pozwoliły na lokalizację miejsc zamieszkania wyszczególnionych osób, ale także umożliwiły odtworzenie topografii żydowskiego miasta (il. 18 bramy i łaźnie).

Wspominany już Marek Kamieniecki w latach 1694-1708 był starszym synagogi i przez kilkanaście lat brał czynny udział w życiu wspólnoty religijnej Podzamcza, także jako syndyk żydowski i reprezentant synagogi w sprawach spłaty i egzekucji długów ${ }^{42}$. Jednak przed tym okresem był aktywnym handlarzem, kupcem i korzennikiem. W $1693 \mathrm{r}$. wraz ze swym najstarszym synem, wymienionym powyżej Perecem Markiem Kamienieckim, wykupili zastawione przez Adama Stryjkowskiego złoto i klejnoty od Żyda - Eliasza Kony. Po tym akcie Kamienieccy chcieli także szantażem od Stryjkowskiego uzyskać dostęp do pomieszczenia na sklep korzenny w kamienicy Stryjkowskiego - tego samego, które wynajmował właśnie Eliaszowi Konie ${ }^{43}$. Kolejną wzmianką wiążącą Marka i Pereca z Adamem Stryjkowskim był incydent $\mathrm{z}$ tego samego, $1693 \mathrm{r}^{44}$, kiedy to Kamienieccy wywieźli z dwu sklepów należących do Alkony Jakubowicza cały jego towar, podczas pobytu Alkony w Gdańsku. Pierwszy sklep znajdował się w kamienicy zwanej „Bargłowską" - przy ul. Grodzkiej, a drugi w kamienicy złotnika Stryjkowskiego (il. 19 kamienice i sklepy). Swoje straty Alkona wycenił na 8 tys. złp. Przyczyną takiego zachowania Kamienieckich była chęć wyegzekwowania długu od Alkony ${ }^{45}$.

Następny wpis dotyczący Kamienieckich pochodzi z 1694 r. Wynika z niego, że kupiec gdański Salomon Wondereme domagał się w sądzie od Marka i Pereca Kamienieckich spłaty pożyczonych 2 lata wcześniej 850 złp $^{46}$. Sąd nakazał spłatę długu pod karą wieczystej banicji. Na podstawie kolejnej wzmianki $\mathrm{z}$ tego samego roku powiązano Kamienieckich z następnym długiem - tym razem winni byli oni kupcowi lubelskiemu Danielowi Fejkowi, plenipotentowi

\footnotetext{
41 Ibidem, s. 27, nr 88.

42 Materiały źródłowe 1, nr 411, 608, 712.

43 Materiały źródłowe 2, s. 301, nr 1850.

44 Ibidem, s. 303, nr 1860.

45 Ibidem, s. 304, nr 1867.

46 Ibidem, s. 317, nr 1951.
} 
gdańskiego kupca Salomona Wondereme, spłaty w ciągu 8 tygodni 850 złp ${ }^{47}$. Wskutek braku zdolności spłaty długu Kamienieccy pozwolili na intromisję do swojej kamienicy przy ul. Żydowskiej ${ }^{48}$. Jednak do przejęcia kamienicy nie doszło i kupiec Daniel Fejk musiał domagać się w sądzie ogłoszenia wieczystej banicji dla Kamienieckich. Jednocześnie Marek Kamieniecki wystąpił o kasatę dekretu spłaty 850 złp dla kupca Fejka i udowadniał, że część długu spłacił już w towa$\mathrm{rze}^{49}$. W konsekwencji sporu, pod koniec 1694 r. Perec, syn Marka Kamienieckiego, został zamknięty w wieży grodzkiej ${ }^{50}$, a na początku $1695 \mathrm{r}$. Kamienieccy ostatecznie spłacili cały dług gdańskiemu kupcowi ${ }^{51}$.

Późniejsze wzmianki źródłowe wspominają mieszkających nieopodal Marka Kamienieckiego jego synów - Icka, Mendela Markowicza z żoną Gaudą, i córkę Zyskę Majerową z mężem Majerem Dawidowiczem ${ }^{52}$. Zapewne jeszcze w $1708 \mathrm{r}$. Marek Kamieniecki nie był już przedstawicielem gminy. Za ociąganie się w spłacie długu 220 złp za wzięty miód od pisarza prowentów Wojciecha Niedźwieckiego sąd nałożył na Marka karę wieczystej banicjii ${ }^{53}$, a asekurację długu zabezpieczono w kamienicy Marka. Kamienica położona była „obok mostu” w „mieście Żydowskim”. Niedźwiecki nie dokonał przejęcia kamienicy, ponieważ pretensje do niej zgłosiła cała rodzina Kamienieckich ${ }^{54}$. Niedługo po tych wydarzeniach Marek Kamieniecki zmarł, a jego syn Mendel odziedziczył po ojcu tylko długi, gdyż w sądzie przysięgał, że „po ojcu nie odziedziczył żadnego majątku, żadnych pieniędzy i towarów, nie może spłacić długów ojca". Przekonał tym sędziego i sąd grodzki anulował zasądzone wcześniej kary ${ }^{55}$. Pięć przed śmiercią Marka oblatowano jeszcze ważny dokument z czasów, gdy był starszym synagogi. Sprawa dotyczyła zaciągniętej w 1694 r. przez synagogę dużej sumy - 5000 złp - pożyczki asekurowanej na majątku gminy żydowskiej. Tak wielką kwotę pożyczono na 7 lat od przeora lubelskiego konwentu karmelitów Anastazego Hermanowskiego ${ }^{56}$. W 1718 r., dziesięć lat po śmierci Marka, jego najmłodszy syn - Icek Kamieniecki - uregulował także sprawę długu ojca $\mathrm{z}$ wdową po wspominanym w 1693 r. Alkonie

\footnotetext{
47 Ibidem, s. 322-325, nr 1984, 1988, 2000.

48 Ibidem, s. 327-328, nr 2016, 2018.

49 Ibidem, s. 332-333, nr 2050, 2052.

50 Ibidem, s. 337, nr 2082.

51 Ibidem, s. 337, nr 2084.

52 Materiały źródłowe 1, s. 148, nr 712.

53 Ibidem, s. 151, nr 731.

54 Ibidem, s. 152, nr 737.

55 Ibidem, s. 164, nr 808.

56 Ibidem, s. 208, nr 1073. Brak danych na temat spłaty długu.
} 
Jakubowiczu ${ }^{57}$. Tak interesującą historię można było opowiedzieć wyłącznie dzięki połączeniu wielu różnych zapisek źródłowych.

Inaczej wyglądała sprawa związana z rodziną Bera Michałowicza ${ }^{58}$ - syna zmarłego Michała Śliwki (il. 20 rodzina Bera Michałowicza). Wpis źródłowy z początku 1651 r. wzmiankuje Bera Michałowicza wraz z żoną Itą i swoim teściem Michałem Niemcem - sędzią żydowskim, podczas oblaty aktu sprzedaży swojej kamienicy na Podzamczu lwowskiemu Żydowi Samuelowi Judowiczowi za cenę 4800 złp. Kamienica Bera Michałowicza położona była pomiędzy domami Lewka Moszkowicza - starszego cechu rzeźników, i Icka Doktorowicza - seniora gminy żydowskiej ${ }^{59}$. Można tu nadmienić, że senior gminy, jako reprezentant społeczności żydowskiej, mógł liczyć na specjalne względy. W jego obronie w 1663 r. stanął sam król Polski Jan Kazimierz. Wystawił na jego imię list żelazny, aby dać czas na wyjaśnienia $\mathrm{w}$ toczącej się już sprawie z pozwu starosty garwolińskiego Andrzeja Ostroroga ${ }^{60}$. Jeszcze kilka razy Icek Doktorowicz był wzmiankowany w źródłach - głównie jako reprezentant gminy w pozwach skierowanych przeciw władzom społeczności żydowskiej.

Na marginesie przypominamy, że usługi na polu ekonomicznym świadczone przez Żydów magnatom zapewniały im ochronę przed potencjalnymi przeciwnikami, choć magnaci stanowili tylko małą część polskiej szlachty. W zdecydowanej większości szlachta nie posiadała wielkich latyfundiów, nie zajmowała miejsc w Senacie ani nie znajdowała posłuchu u samego króla. W najlepszym razie była w posiadaniu małych majątków lub pełniła służbę urzędniczą u króla czy jakiegoś magnata. Dlatego też ze współpracy z Żydami korzystała w zdecydowanie mniejszym stopniu niż magnateria - w odróżnieniu od niej bowiem dochód przeciętnego szlachcica tylko w niewielkim stopniu pochodził z działalności ekonomicznej prowadzonej przez Żydów ${ }^{61}$.

Wracając do połączeń sąsiedzkich związanych z rodziną wspominanego Bera Michałowicza, nie można pominąć wspomnianego sąsiada Bera - Icka Doktorowicza i jego siostry Fejgieli, która w 1647 r. wraz z mężem Ickiem Jakubowiczem nabyła dom murowano-drewniany od Bera Moszkowicza. Dom ze sklepem położony był pomiędzy posesjami Żydów Moszka Kantora i Dawida Lipy. Icek Jakubowicz, jak i jego brat Lewek Jakubowicz, kupiec lubelski, byli uczestnikami i ofiarami

\footnotetext{
57 Ibidem, s. 248, nr 1317.

58 <http://www.teatrnn.pl/ludzie/osoby/id/Iooo24995/> [dostęp: 3.02.2021].

59 Materiały źródłowe 3, s. 108, nr 605, 608.

60 Ibidem, s. 152, nr 890.

61 Ibidem, s. 167, 169, 170, 171, nr 984-5, 993, 999, 1011.
} 
tumultów, do jakich często dochodziło podczas pożogi wojennej na przestrzeni lat $1646-1666^{62}$. Przed tym okresem Icek posiadał jeszcze dom, który w 1633 r. sprzedał Żydowi Dawidowi Salomonowiczowi za 8000 złp. Dom położony był na ul. Żydowskiej, na rogu uliczki prowadzącej do rzeźni żydowskiej, obok domu Szaji Kokoszki ${ }^{63}$. Niedługo później Dawid Salomonowicz świeżo kupiony dom sprzedał z zyskiem za 8500 złp $^{64}$.

Równie intrygującą historią są perypetie kupca Józefa Salomonowicza i jego rodziny ${ }^{65}$. Wzmianki datowane na rok 1659 wspominają Józefa, który pozywa Katarzynę Giernową, wdowę po kupcu Janie Giernerze, odnośnie do uregulowania spłaty długu. Jako zabezpieczenie spłaty długu Żyd Józef miał przejąć kamienicę „Giernerową" (il. 21 rodzina Józefa Salamonowicza). Nie doszło do tego, gdyż wdowa wymówiła się dekretem z sądu zadwornego ${ }^{66}$. W podobnej sytuacji Józef Salomonowicz znalazł się 2 lata później ${ }^{67}$. Przy okazji przytoczonej wzmianki źródłowej dowiadujemy się o innych członkach rodziny Salomonowicza - o jego siostrze Sarze, wdowie po Matysie Moszkowiczu, oraz bracie Lewku, seniorze gminy lubelskiej. Wartościową informacją jest także opis położenia jego kamienicy przy ul. Żydowskiej. Jego sąsiadem był Kaufman Chaimowicz, syn Chaima Markowicza. Na podstawie wyżej przytoczonych historii można wyraźnie zaobserwować proceder skupowania długów i asekurowania ich w nieruchomościach. Ostatnim zapisem jest datowany na 1689 r. akt $z$ sądu grodzkiego o uregulowaniu przez Józefa długów na rzecz mieszczanina lubelskiego Kazimierza Bawarskiego ${ }^{68}$.

Przedstawiony poniżej na podkładzie Pożaru miasta Lublina z 1719 r. schemat powiązań sąsiedzkich (zobacz: il. 11) ukazuje rozbudowaną siatkę rodzinnych relacji i wzajemnych zależności między nimi (np. transakcje zbycia/cesji nieruchomości zaznaczane przerywaną strzałką). Zawarte w zapiskach źródłowych precyzyjne dane dotyczące położenia poszczególnych kamienic i domów, wraz z umiejscowionymi w ich pobliżu charakterystycznymi punktami (tj. Brama Grodzka, łaźnia ${ }^{69}$, bożnica itd.), pozwoliły odtworzyć prawdopodobne lokalizacje konkret-

62 Ibidem, s. 81-82, 105-106, 147, nr 443, 446-447, 591, 593, 856.

63 Ibidem, s. 23, nr 57.

64 Ibidem, s. 24, $\mathrm{nr} 65$.

65 <http://www.teatrnn.pl/ludzie/osoby/id/Iooo14316/> [dostęp: 3.02.2021].

66 Materiały źródłowe 3, s. 132, $\mathrm{nr} 762$.

67 Ibidem, s. 145-6, nr 846-847.

68 Materiały źródłowe 2, s. 216, nr 1307.

69 J. Jeremicz, P. Zimny, <http://www.teatrnn.pl/leksykon/artykuly/laznie-zydowskie-w-lublinie/> [dostęp: 12.11.2020]. 
nych budynków wraz z wzajemnymi relacjami ich właścicieli w czasie określonym zapisem źródłowym.

Podążając za poniższym schematem powiązań sąsiedzkich, można zauważyć, że wdowa po Lewku Aronowiczu ${ }^{70}$, Estera Aronowiczowa, wraz z synami: Jakubem Lewkowiczem, Ickiem Lewkowiczem, Jowelem Lewkowiczem, Józefem Lewkowiczem i Moszkiem Lewkowiczem, zmuszona była zapisać darowiznę na rzecz szlachcica Kazimierza Bielskiego, cześnika warszawskiego i podstarosty lubelskiego. Akt darowizny wymuszony był niemożliwością spłaty zaciągniętego niegdyś przez Lewka długu. W darowiźnie przepisała swoje dobra dziedziczne kamienicę z placem przy ul. Żydowskiej (zwanej też Szeroką) w Lublinie. Omawiana kamienica znajdowała się pomiędzy kamienicami Eliasza Mendlowicza i Icka Berkowicza Czarnego ${ }^{71}$.

Następnie wymienić należy sąsiada Lewka - Eliasza Mendlowicza, który z żoną Małką miał dwóch synów: Icka Eliaszowicza i Manela Eliaszowicza ${ }^{72}$. Szczególnie ten ostatni, z racji swojej aktywności kupieckiej, a także pełnionej funkcji seniora synagogi lubelskiej, często był wymieniany w księgach grodzkich lubelskich z lat 1697-1733. Dalej mieszkał Szymon Percowicz Szmuklerz, który swoją kamienicę przy ul. Żydowskiej, położoną pomiędzy kamienicami Lewka Baryły i Lewka Żorkeiwicza, zapisał sąsiadce wspomnianego wcześniej Lewka Aronowicza i wdowie po Icku Czarnym - Cyrii Ickowiczowej. Łaźnię stojącą obok zapisanej kamienicy odstąpił swemu bratu - Tobiaszowi Percowiczowi ${ }^{73}$ (zobacz: il. 18). Dodatkowym zapisem precyzującym położenie domu Lewka Baryły była oblata wpisu z ksiąg wójtowskich lubelskiego Podzamcza z 29 grudnia 1700 r., która lokalizuje dom Lewka przy Bramie Grodzkiej ${ }^{74}$. Zapis z 1711 r. wspominał jeszcze o złotniku Berku Mendlowiczu i jego żonie Berli, których dom sąsiadował z domem wymienianego Lewka Aronowicza, kamienicą Moszka Dawidowicza, a także placem przy ul. Żydowskiej, między szkołą żydowską (bożnicą) i mieszkaniem Moszka Szkolnika ${ }^{75}$. Notabene nazwisko i położenie mieszkania Moszka Szkolnika w pobliżu bożnicy nie jest przypadkowe. Wobec jeszcze niewykształconych nazwisk, przy

\footnotetext{
70 <http://www.teatrnn.pl/ludzie/osoby/id/Iooo17867/> [dostęp: 3.02.2021].

71 Materiały źródłowe 1, s. 148, nr 713.

72 Ibidem, s. 45-46, 261, nr 68, nr 1398.

73 Ibidem, s. 153, nr 742.

74 Ibidem, s. 163, nr 80o. Zob. <http://www.teatrnn.pl/wydarzenia/wydarzenie/sprawa-bram-zydowskich-w-lublinie/> [dostęp: 12.11.2020].

75 Materiały źródłowe 1, s. 185, nr 929.
} 
imionach Żydów często występowały przydomki powiązane z wykonywanym zawodem, tj. wspominany Moszek Szkolnik ${ }^{76}$ i szkoła żydowska.

W sferze działań gospodarczych szlachta często dokonywała tego rodzaju inwestycji. Zapisy żydowskich nieruchomości pod zastaw zaciągniętych długów były chętnie akceptowane przez Żydów. Niosły za sobą jednak ryzyko, że w razie niespłacenia długu dom przejdzie w ręce nieżydowskie ${ }^{77}$.

Na przykład w 1708 r. na poczet niespłaconego długu zakon dominikanów przejął częściowo kontrolę nad jedną z lubelskich synagog, a w 1714 r. gmina żydowska w Lublinie nie była w stanie zmienić swojego arendarza pod presją jezuitów, którym pozostawała dłużna znaczną sumę pieniędzy zabezpieczonych podatkiem zwanym $\mathrm{krobkąa}^{78}$. Żydzi ze swej strony czasami starali się nie dopuścić do tego, aby należące do nich nieruchomości przeszły w posiadanie Kościoła - w księgach grodzkich znajdujemy przynajmniej dwa przypadki, kiedy udało im się zapobiec czerpaniu przez księży dochodu z żydowskich domów, które stały się ich własnością.

\section{Zakończenie}

W poniższym tekście przedstawione zostały wstępne efekty realizacji projektu konwersji akt sądowych ksiąg grodzkich lubelskich z lat 1633-1733 do bazy danych i korzyści płynące z analizowania danych źródłowych przy wykorzystaniu edycji bazodanowych.

Łącząc osoby z opisami położenia niektórych nieruchomości, stworzono wizualizacje, które ilustrują możliwości edycji bazodanowych i mogą być wiarygodnym źródłem do ustalenia miejsca zamieszkania wybranych osób w żydowskim mieście. Udało się także zbudować historie o kilku rodzinach i ich drzewa genealogiczne. Baza danych mieszkańców lubelskiego Podzamcza została uzupełniona informacjami zawartymi na dawnych mapach Lublina. Infografiki i ilustracje ukazują związki rodzinne i dynamikę sąsiedztwa. Zestawienie tych danych pozwoliło określić, gdzie mogli mieszkać żydowscy i chrześcijańscy właściciele domów oraz gdzie istniały podzameckie budynki publiczne. Infografiki tworzą swoistą mapę osadniczą dla historycznego Podzamcza, która sama w sobie może być przyczynkiem do przyszłych studiów socjotopograficznych i odtwarzania topografii miasta żydowskiego.

\footnotetext{
76 Materiały źródłowe 2, s. 11.

77 Materiały źródłowe 1, s. 23.

78 Materiały źródłowe 1, s. $88 \mathrm{nn}$.
} 
Artykuł nie wyczerpuje mnogości możliwości interpretacji danych zawartych w księgach. Nakreśla jedynie kierunki ewentualnych dociekań, które mogą być przyczynkiem do przyszłych studiów socjotopograficznych. Zaproponowany schemat kryteriów może być dowolnie rozbudowywany i może posłużyć do relacyjnego powiązania informacji o osobach i miejscach z innymi istniejącymi już bazami danych.

Śmiało można powiedzieć, że księgi grodzkie są jednym z najważniejszym źródeł do dziejów wyznawców judaizmu w Lublinie. Uwypuklają wielki historiograficzny potencjał regestrów jako źródeł do badania historii Żydów mieszkających w Polsce na przestrzeni wieków. Pokazują skalę powiązań gospodarczych między Żydami a szlachtą oraz mieszczaństwem, a także instytucjami kościelnymi (kapituły, parafie, zakony, kolegia). Zawierają dane o miejscach ich zamieszkania, relacjach rodzinnych, zawodach, jakie wykonywali, oraz o wydarzeniach, w których uczestniczyli - genealogiczny aspekt we wczesnych dokumentach grodzkich jest wyraźnie reprezentowany. Grodzkie akta sądowe z XVII i XVIII w. zawierają również liczne informacje o kupcach żydowskich przybywających z różnych miast Polski i Europy.

Według prof. Henryka Gmiterka, księgi grodzkie lubelskie do badań nad Żydami wykorzystywane były dotąd w znikomym stopniu, sporadycznie. Tymczasem ich wartość źródłowa jest tym większa, że zapiski dotyczą nie tylko Żydów z Lublina i Lubelszczyzny, ale także przybyszów z najodleglejszych zakątków Rzeczypospolitej i zagranicy, handlujących tutaj bądź załatwiających swoje sprawy w trybunale. I chociaż wpisy odnoszące się do Żydów stanowią zazwyczaj jedynie znikomy procent wszystkich zapisów, to pokazują całe bogactwo spraw i problemów, z jakimi sami Żydzi przybywali do sądu i urzędu grodzkiego, bądź też byli tam pozywani, a w tle sytuację społeczną i ekonomiczną całego miasta.

\section{Summary}

\section{From Raw Data to Visualization. A Database for the History of Inhabitants of Lublin's Podzamcze District of 1633-1733}

The goal of the paper is to show the potential existing in the information on the Jewish population inhabiting the Podzamcze district contained in Lublin's town registers of 1633-1733. The article seeks to study the problem of presenting Big Data in an accessible form. By using a database management system, the author carries out a statistical analysis of the obtained data, draws conclusions, and outlines the directions of future research. He introduces the historical and economic background, discusses family relationships and changes in the dynamics of the neighborhood and 
population migration, as well as telling the histories of several families and showing their genealogical trees. He presents selected professions and shows the numerical strength and activity of individual occupational groups, and represents selected research results in the form of infographics and illustrations. The author also provides an outline of the sociotopographic map of the Jewish Town complemented with the information contained in the old maps of Lublin. The paper is a synthesis of the hitherto collected information, and an attempt to look more broadly at the capabilities contained in this type of projects, in which data processing and analysis is difficult but at the same time valuable and leading to gaining new knowledge.

\section{Bibliografia}

\section{Źródła drukowane}

Dzieje Żydów w Polsce. Wybór tekstów źródłowych XI-XVIII w., oprac. P. Fijałkowski, Warszawa 1993.

Materialyźródłowe do dziejów Żydów w ksiegach grodzkich lubelskich z doby panowania Augusta II Sasa 1697-1733, oprac. H. Gmiterek, Lublin 2001.

Materiaty źródłowe do dziejów Żydów w księgach grodzkich lubelskich $z$ doby panowania Michała Korybuta Wiśniowieckiego i Jana III Sobieskiego 1669-1697, oprac. H. Gmiterek, Lublin 2003.

Materialy źródłowe do dziejów Żydów w księgach grodzkich lubelskich $z$ doby panowania Wtadystawa IV i Jana Kazimierza Wazów 1633-1669, oprac. H. Gmiterek, Lublin 2006.

Materialy źródłowe do dziejów Żydów w księgach grodzkich lubelskich $z$ doby panowania Zygmunta III Wazy, oprac. H. Gmiterek, Lublin 2014.

\section{Literatura}

Bałaban M., Żydowskie miasto w Lublinie, Lublin 1991.

Bogucka M., Miasto i mieszczanin w spoleczeństwie Polski nowożytnej (XVI-XVIII wiek), „Czasy Nowożytne”, t. 22, 2009, s. 9-49.

Bogucka M., Samsonowicz H., Dzieje miast i mieszczaństwa w Polsce przedrozbiorowej, Warszawa 1986.

Chachaj J., Czwartek, Ponikwoda, Podzamcze i Słomiany Rynek do początków XVII w., [w:] Lublin. Historia Dzielnic w 7oo. rocznicę lokacji miasta, red. J. Chachaj, H. Mącik, D. Szulc, Lublin 2017, s. 338-345.

Dzieje Lubelszczyzny, red. T. Mencel, Warszawa 1974.

Gmiterek H., Lublin w stuleciach XVII i XVIII, [w:] Lublin. Dzieje miasta, t. 1, Od VI do końca XVIII w., red. R. Szczygieł, H. Gmiterek, P. Dymmel, Lublin 2008. 
Lublin. Przewodnik, oprac. P. Kawałko, Z. Nestorowicz, Lublin 2012.

Kaźmierczyk A., Rodziłem się Żydem... Konwersje Żydów w Rzeczypospolitej XVII-XVIII wieku, Kraków 2015 (Studia Judaica Cracoviensia).

Krawczyk A., Szkoci w Lublinie i Lubelskim w XVII wieku, „Rocznik Lubelski”, t. 35, 2009, s. $77-86$.

Mark B., Rzemieślnicy żydowscy w Polsce feudalnej, „Biuletyn Żydowskiego Instytutu Historycznego", 1954, nr 11-12, s. 74-78.

Mazurkiewicz J., Jurydyki lubelskie, Wrocław 1956.

Mazurkiewicz J., Lublin w okresie reform (1764-1795), [w:] Dzieje Lublina. Próba syntezy, t. 1, red. J. Mazurkiewicz, Z. J. Hirsz, Lublin 1965.

Mazurkiewicz J., Własność i zmiany w stosunkach własnościowych w Lublinie w latach szessćdziesiątych XIX stulecia, „Rocznik Lubelski”, t. 6, 1963, s. 169-184.

Niedźwiadek R., Tkaczyk J., Kalinowszczyzna, Ponikwoda, Czwartek. O średniowiecznym Czwartku, Kalinowszczyźnie i Ponikwodzie, [w:] Lublin. 7oo-lecie. Historia dzielnic, red. D. Szulc, H. Mącik, Lublin 2017, s. 1-48.

Riabinin J., Materiały do historii miasta Lublina 1317-1792, Lublin 1938.

Riabinin J., Materiały do lubelskiego słownika aktowego, Lublin 1924.

Riabinin J., Materiały do lubelskiego słownika aktowego, Lublin 1934.

Szuchta R., 1000 lat historii Żydów polskich. Podróż przez wieki, Warszawa 2015.

Szczygieł R., Konflikty społeczne w Lublinie w pierwszej połowie XVI w., Warszawa 1977.

Węgrzynek H., „Czarna legenda” Żydów. Procesy o rzekome mordy rytualne w dawnej Polsce, Warszawa 1995.

Wojciechowski S., Gmina Żydowska w Lublinie w XVI w., „Biuletyn Żydowskiego Instytutu Historycznego", 1952, nr 2, s. 203-240.

Wójciuk M. T., Specyfikacja kamienic i moderacje pogłównego Lublina z 1738 r., „Rocznik Lubelskiego Towarzystwa Genealogicznego", t. 6, 2014, s. 170-278.

Związek T., Wydawać, ale jak? Propozycja cyfrowej edycji staropolskich ksiąg sadowych XV-XVIII w., [w:] Editiones sine fine, t. 1, red. K. Kopiński, W. Mrozowicz, J. Tandecki, Toruń 2017, s. 203-226.

Zimny P., Niedźwiadek R., Grabowski M., Fosa średniowiecznego Lublina i jej otoczenie w świetle badań interdyscyplinarnych, [w:] Krakowskie Przedmieście w 45o-lecie Unii Lubelskiej, red. R. Niedźwiadek, Lublin 2019, s. 201-228.

\section{Strony internetowe}

Ośrodek „Brama Grodzka - Teatr NN” - J. Jeremicz

$<$ http://teatrnn.pl/leksykon/kalendarium/wydarzenie/9527>

$<$ http://teatrnn.pl/podzamcze $>$ 
$<$ http://www.teatrnn.pl/leksykon

$<$ http://www.teatrnn.pl/leksykon/artykuly/podzamcze-jako-jurydyka/>

$<$ http://www.teatrnn.pl/leksykon/artykuly/sejm-czterech-ziem-waad-arba-aracot-15801764/>

$<$ http://www.teatrnn.pl/leksykon/artykuly/slowniczek-terminow-religii-i-kulturyzydowskiej/\#kahal>

<http://www.teatrnn.pl/leksykon/kalendarium/wydarzenie/10848>

$<$ http://www.teatrnn.pl/kalendarium/wydarzenia/osrodek-brama-grodzka-teatr-nnna-38-zydowskiej-konferencji-genealogicznej-grodzka-gate-nn-theatre-centre-atthe-38th-internatio/>

$<$ http://www.teatrnn.pl/ludzie/osoby/id/Iooo14316/>

$<$ http://www.teatrnn.pl/ludzie/osoby/id/Iooo1584o/>

$<$ http://www.teatrnn.pl/ludzie/osoby/id/Iooo17867/ $\geq$

$<$ http://www.teatrnn.pl/ludzie/osoby/id/Iooo24995/>

$<$ http://www.teatrnn.pl/wydarzenia/wydarzenie/sprawa-bram-zydowskich-w-lublinie/> $<$ http://www.teatrnn.pl/wydarzenia/wydarzenie/sprawa-majerowicza-przeciwkoprawoslawnym-mieszczanom-podzamcza-w-lublinie/>

$<$ http://www.teatrnn.pl/wydarzenia/wydarzenie/sprawa-miedzy-jozwowiczem-abractwem-prawoslawnym-3-sierpnia-1671-r/>

$<$ http://www.teatrnn.pl/wydarzenia/wydarzenie/sprawa-seniorow-bractwa-przy-cerkwiprzemienienia-panskiego-i-zydow-lubelskich-25-kwietnia-1693-r-kontynuacja/>

Ośrodek „Brama Grodzka - Teatr NN” - J. Jeremicz, P. Zimny $<$ http://www.teatrnn.pl/leksykon/artykuly/laznie-zydowskie-w-lublinie/> <http://www.teatrnn.pl/leksykon/artykuly/naplyw-ludnosci-do-lublina-w-latach-1633-1733>

$<$ http://www.teatrnn.pl/leksykon/artykuly/zawody-wymieniane-w-ksiegach-grodzkich-w-latach-1633-1733/>

\section{Lubelskie Archiwum Cyfrowe}

<http://www.lac.lublin.pl/dokumenty/xvi-wiek/1576-1597/1595-15-lipca-krakow/> $<$ http://www.lac.lublin.pl/dokumenty/xvii-wiek/1633-1698/1664-miesiac-i-dzien-niewpisane-warszawa/> $<$ http://www.lac.lublin.pl/dokumenty/xviii-wiek/173612-lipca-warszawa/> 


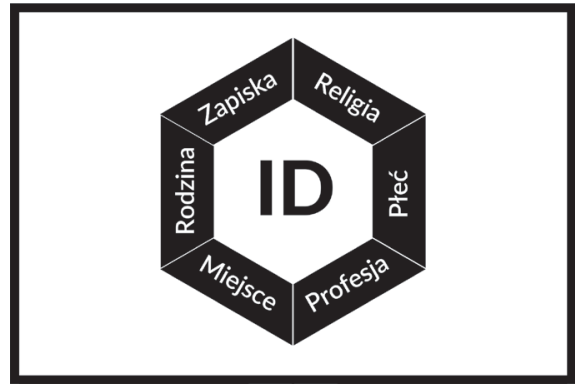

Il. 1. kryteria bazy danych

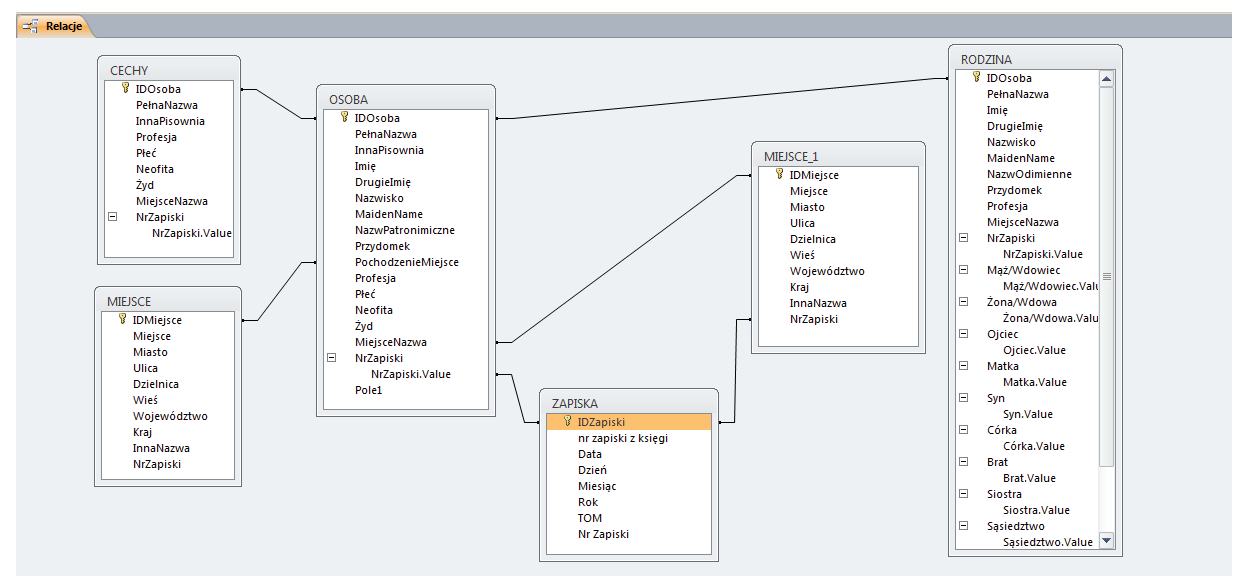

Il. 2. architektura przestrzenna bazy danych

\section{Rozkład ilościowy ID i Zapisek w Księgach}

\begin{tabular}{|c|c|c|c|c|}
\hline & \multirow[b]{2}{*}{ ID } & $100 \%$ & & \multirow[b]{3}{*}{36 lat } \\
\hline & & \multirow[b]{2}{*}{$1697-1733$} & Zapiska & \\
\hline Księga I & 4971 & & 2302 & \\
\hline Księga II & 4501 & $1669-1697$ & 2437 & 28 lat \\
\hline \multirow[t]{2}{*}{ Księga III } & 2149 & $1633-1669$ & 1205 & 36 lat \\
\hline & $\Sigma=11621$ & & $\Sigma=5944$ & 100 lat \\
\hline
\end{tabular}




\section{diagram}

\section{relacja}

miejsce lub punkt

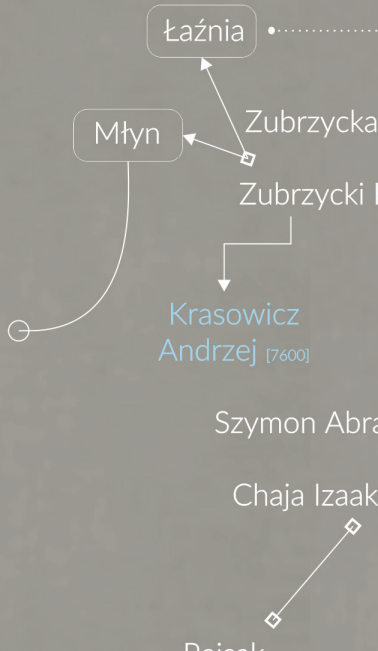

Pejsak

Józwowicz [8777.

charakterystyczny

w terenie

$\rightarrow$ małżeństwo

akt kupna-sprzedaży

nieruchomości

hamowicz [10361]

viczowa [5690]
$\rightarrow$ małżeństwo
$x \cdot \cdots$

relacja sąsiedzka

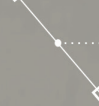

lcek Perec [6645]

$+\quad \cdots \cdots \cdots \cdots \cdots$ matżeństwo

Leja Ickowa [7692].

Lewek Markowicz [7875]

$\rightarrow$ potomstwo

z danego

małżeństwa

Il. 4. klucz do relacji na diagramach 
Rozkład ilościowy i procentowy ID wg kryterium: Religia

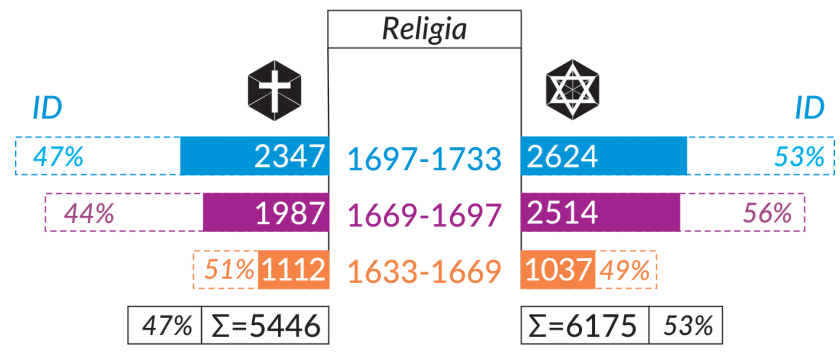

\section{(1) (2)}

Il. 5. rozkład ilościowy i procentowy wg kryterium: Religia

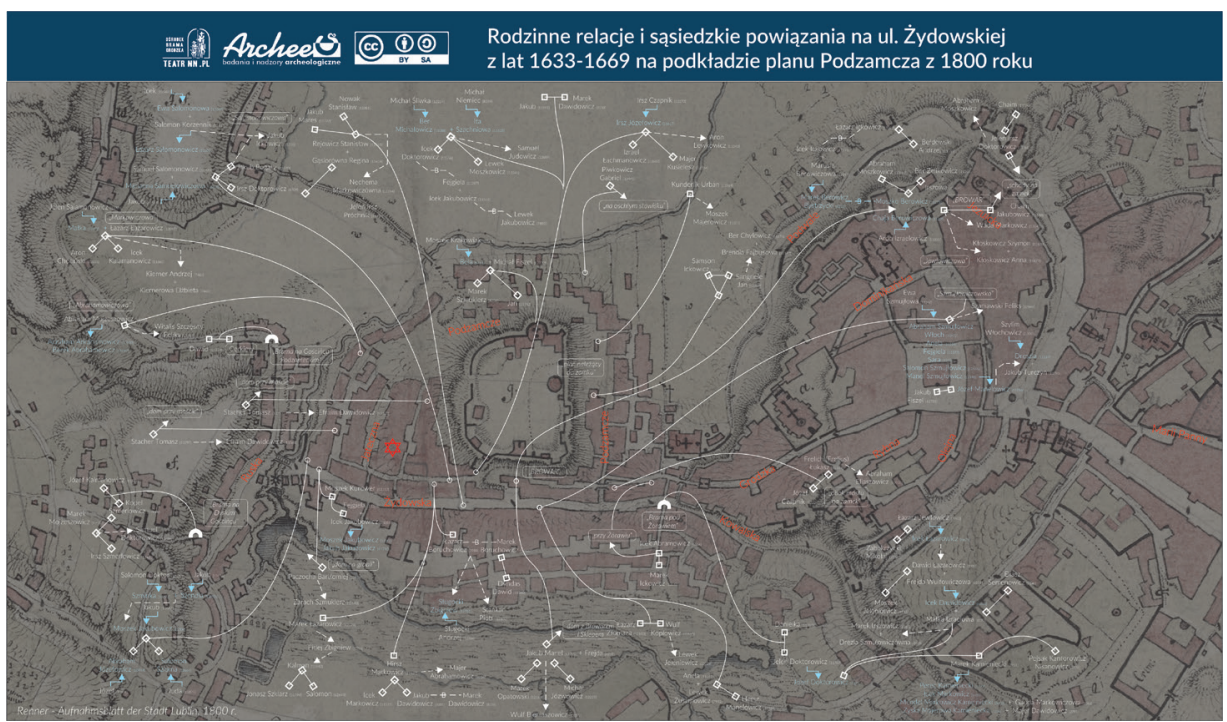

Il. 6. przykład relacji rodzinnych i sąsiedzkich na ul. Żydowskiej 


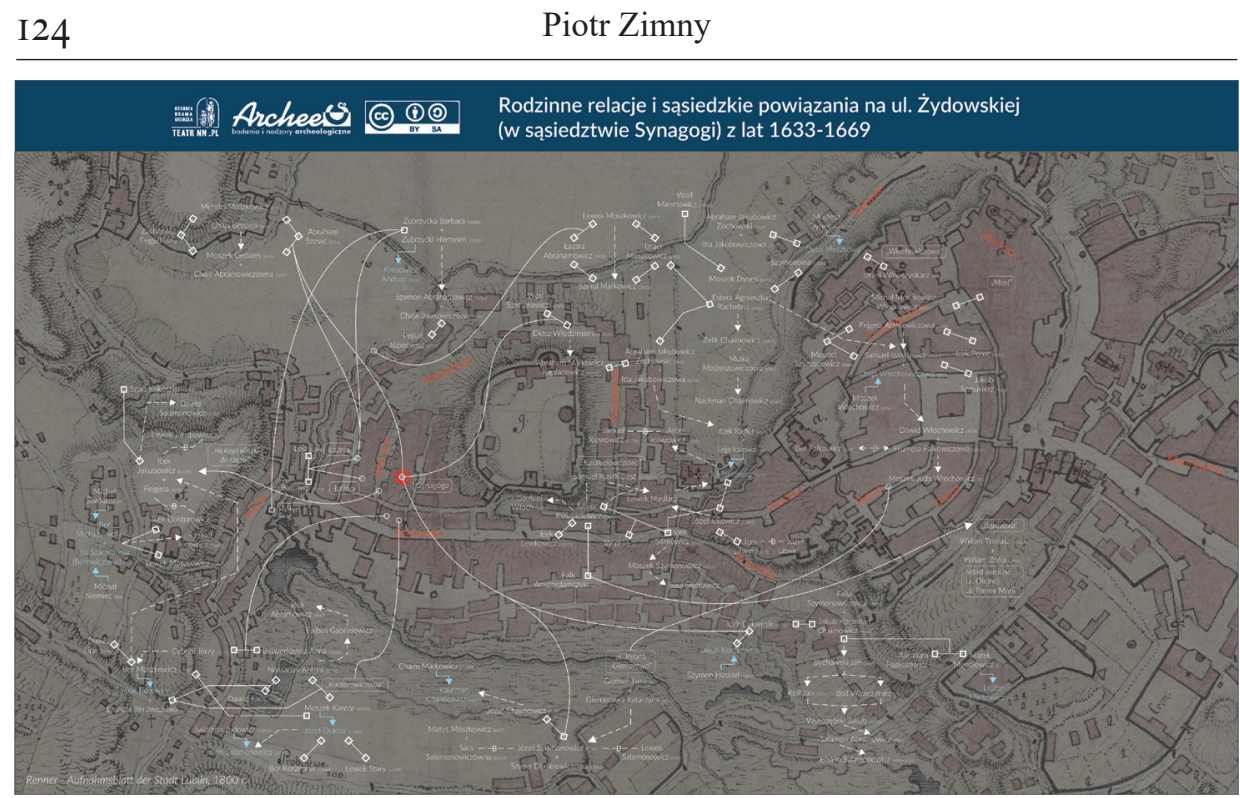

Il. 7. przykład relacji rodzinnych i sąsiedzkich na ul. Żydowskiej

Rozkład ilościowy i procentowy ID wg kryterium: Miejsce

\begin{tabular}{|c|c|c|c|c|c|}
\hline \multirow{2}{*}{\multicolumn{2}{|c|}{ ID }} & & Miejsce & & \multirow[b]{2}{*}{$I D$} \\
\hline & & & \multirow[b]{2}{*}{$\Sigma=2512$} & & \\
\hline I & $24 \%$ & 1215 & & 2387 & $48 \%$ \\
\hline II & $32 \%$ & 1437 & $\Sigma=3909$ & 2472 & $55 \%$ \\
\hline \multirow[t]{2}{*}{ III } & & $40 \% 849$ & $\Sigma=1862$ & $101347 \%$ & \\
\hline & & $\Sigma=3501$ & & $\Sigma=5872$ & \\
\hline
\end{tabular}

(c) (1) (2)

Il. 8. rozkład ilościowy i procentowy wg kryterium: Miejsce 
Rozkład ilościowy i procentowy ID wg kryterium: Powiązania rodzinne / Religia

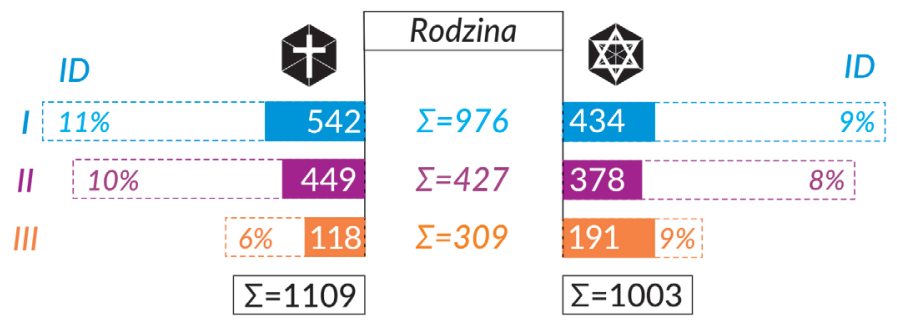

\section{(त) (1) (1)}

Il. 9. rozkład ilościowy i procentowy wg kryterium: Powiązania rodzinne

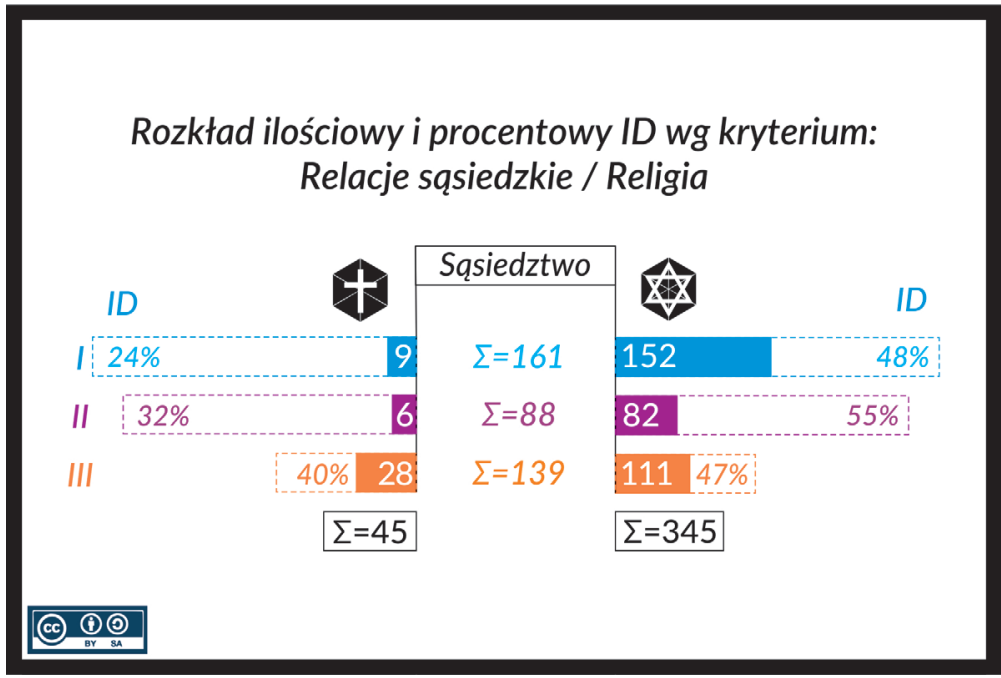

Il. 10. rozkład ilościowy i procentowy wg kryterium: Relacje sąsiedzkie 


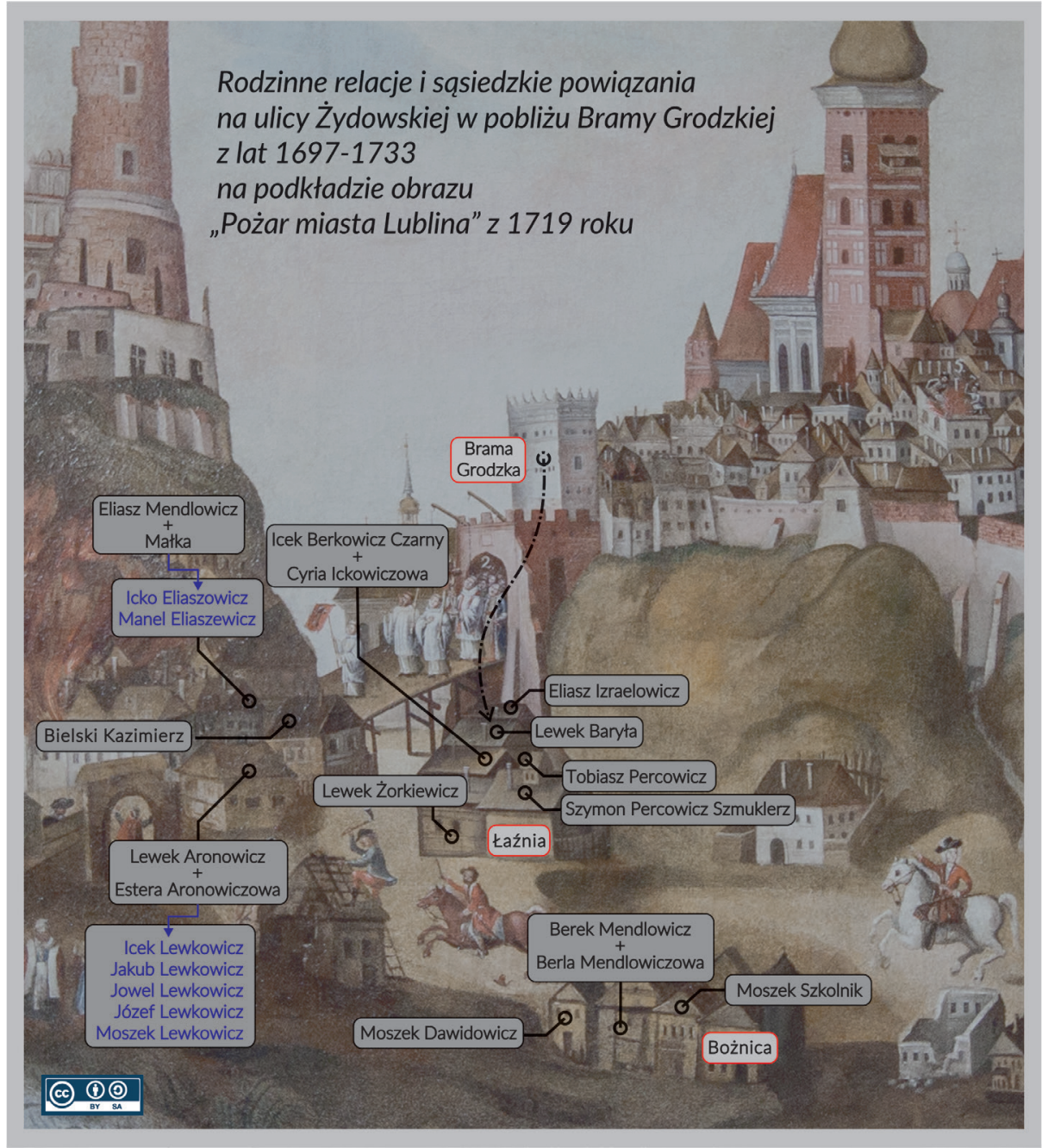

Il. 11. rodzinne relacje i sąsiedzkie powiązania w pobliżu Bramy Grodzkiej 


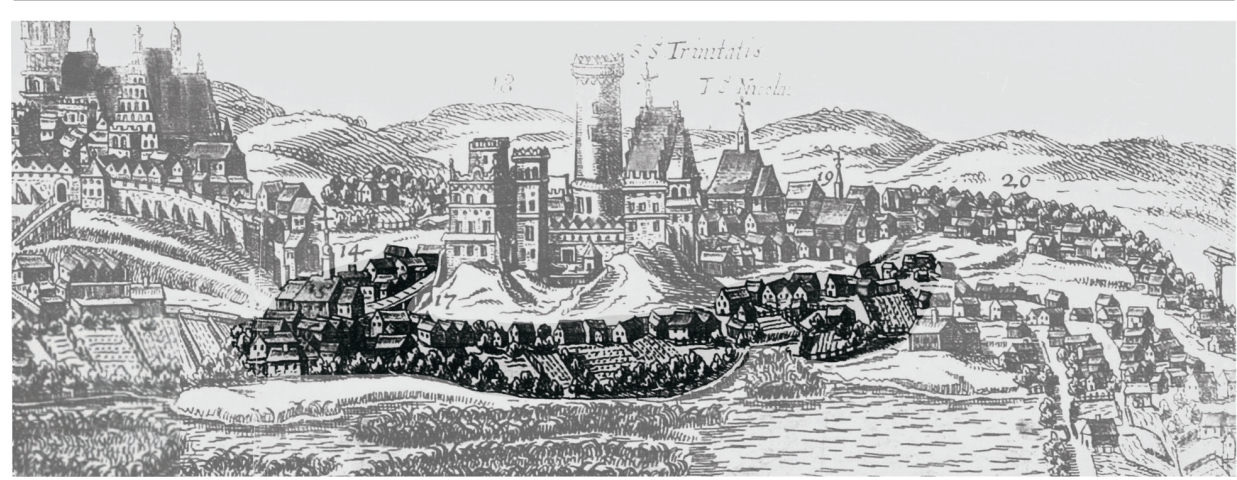

Il. 12. Podzamcze

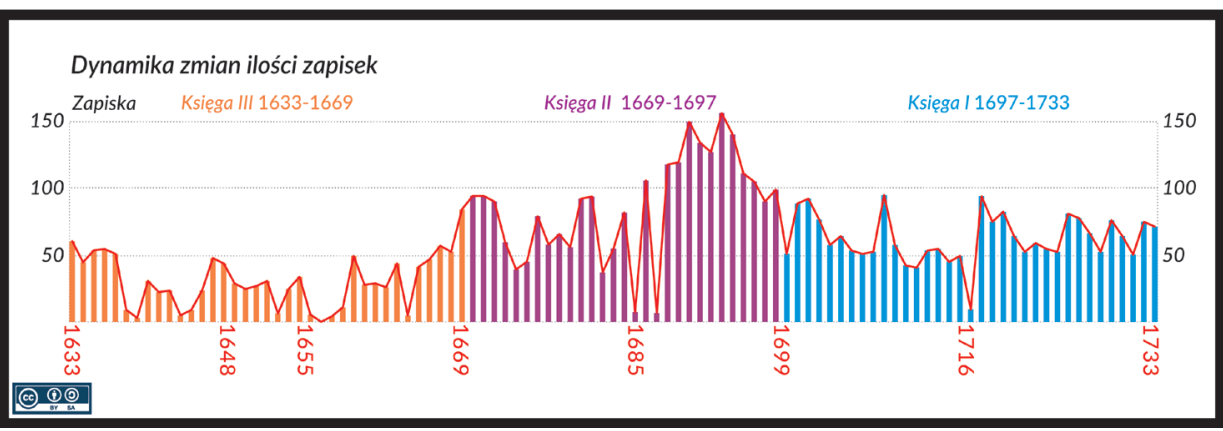

Il. 13. dynamika zmian ilości zapisek

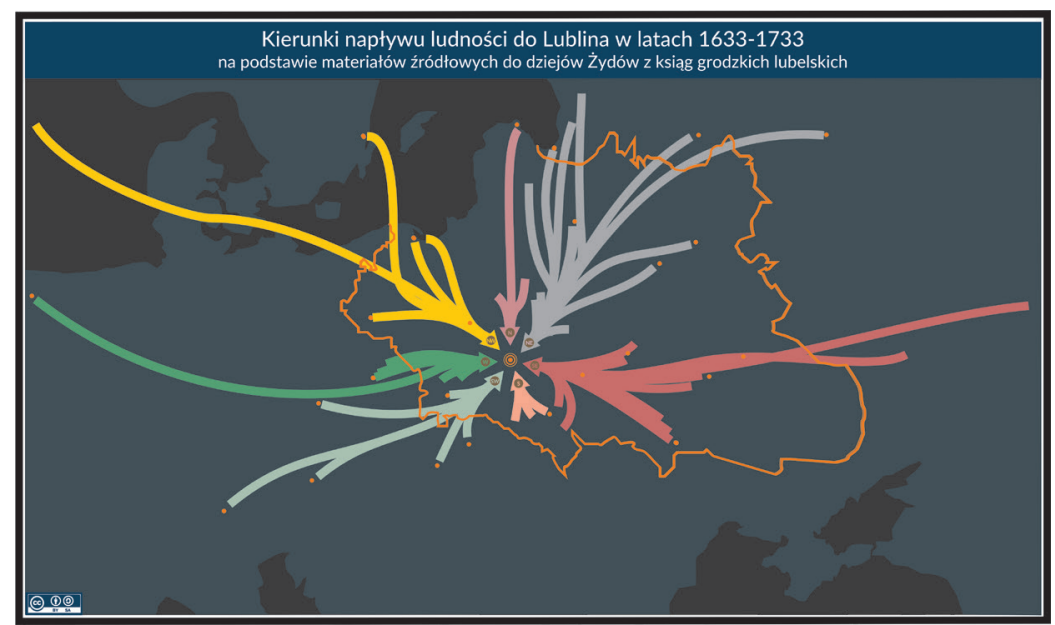

Il. 14. kierunki napływu ludności do Lublina w latach 1633-1733 
Rozkład ilościowy ID wg kryterium: Profesja / Religia

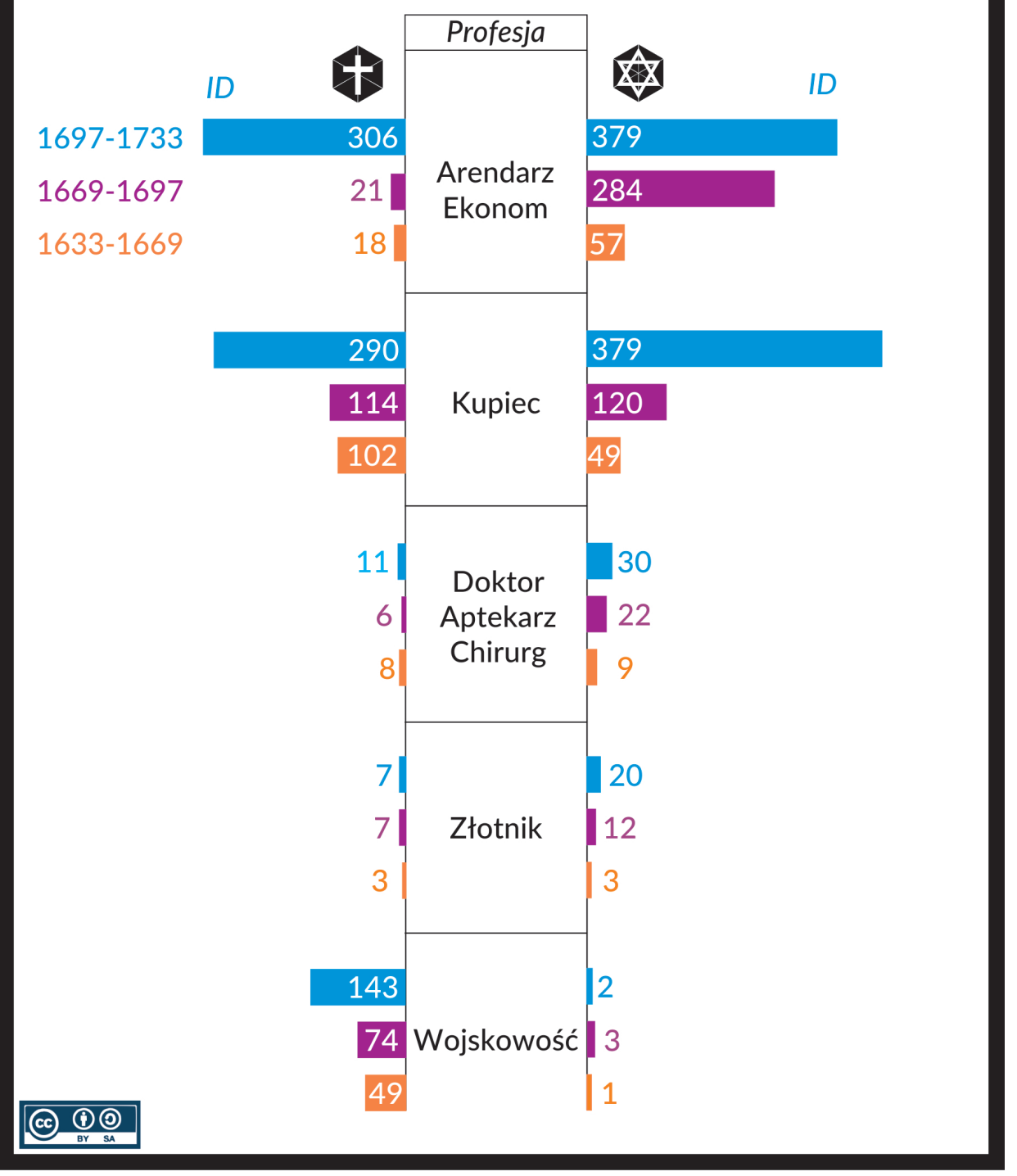

Il. 15. rozkład ilościowy i procentowy wg kryterium: Profesja 


\section{Rozkład ilościowy ID wg kryterium: Profesja / Religia}

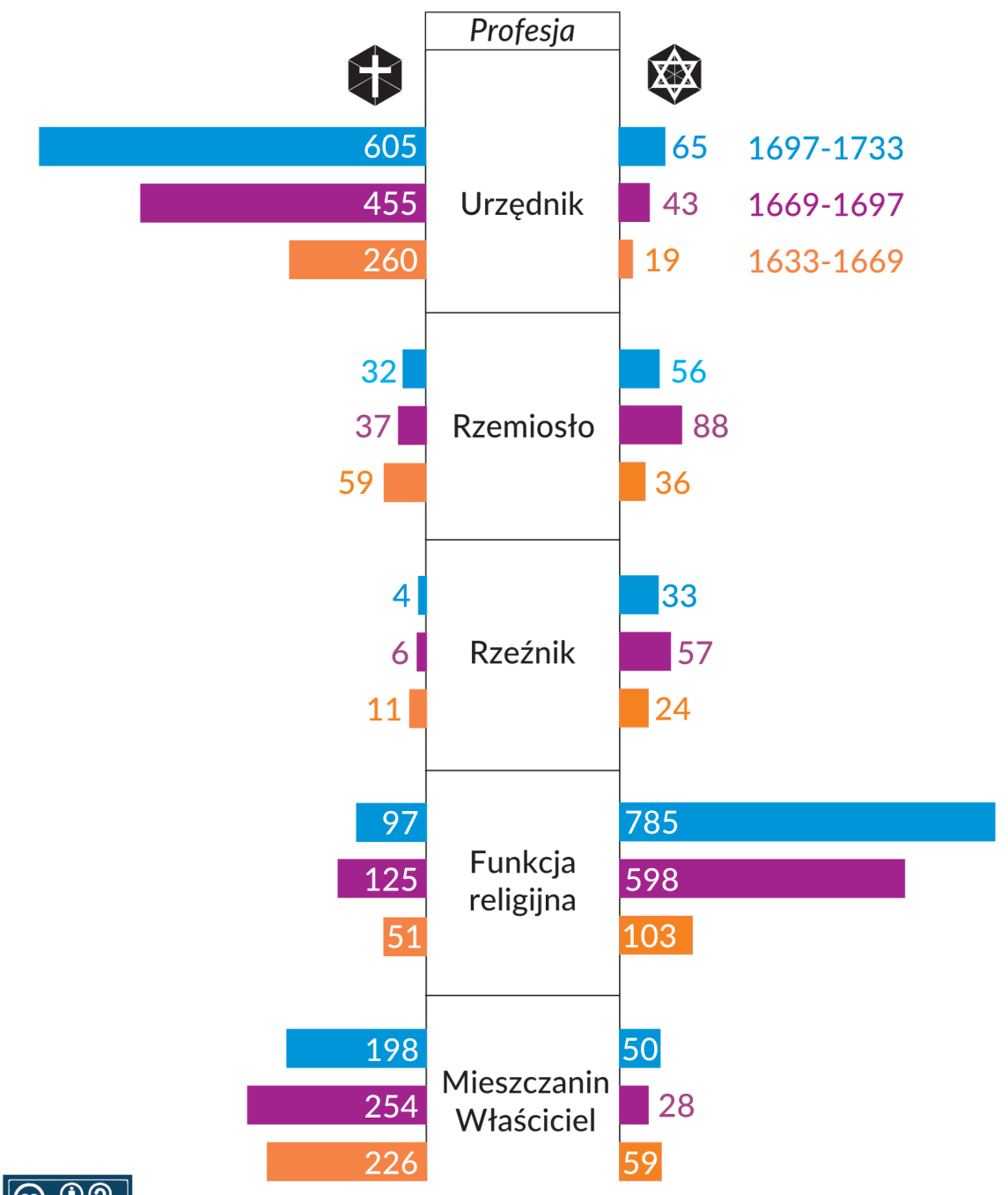

Il. 16. rozkład ilościowy i procentowy wg kryterium: Profesja 


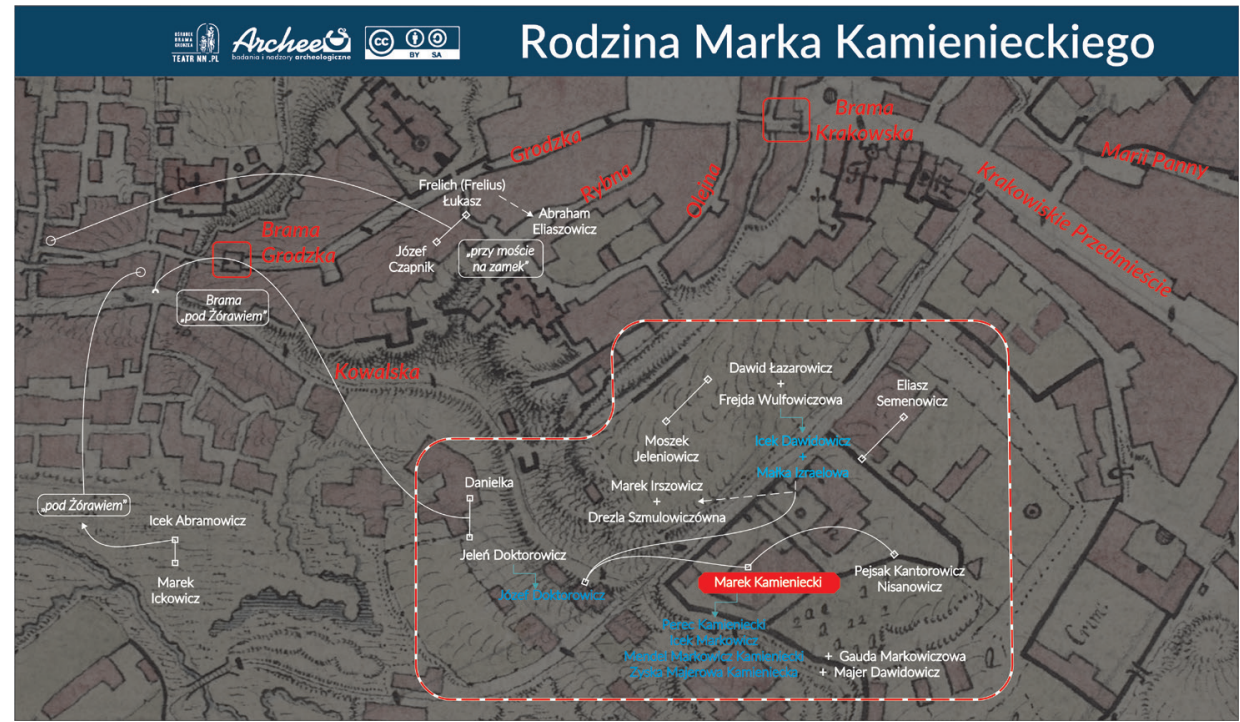

Il. 17. rodzina Marka Kamienieckiego

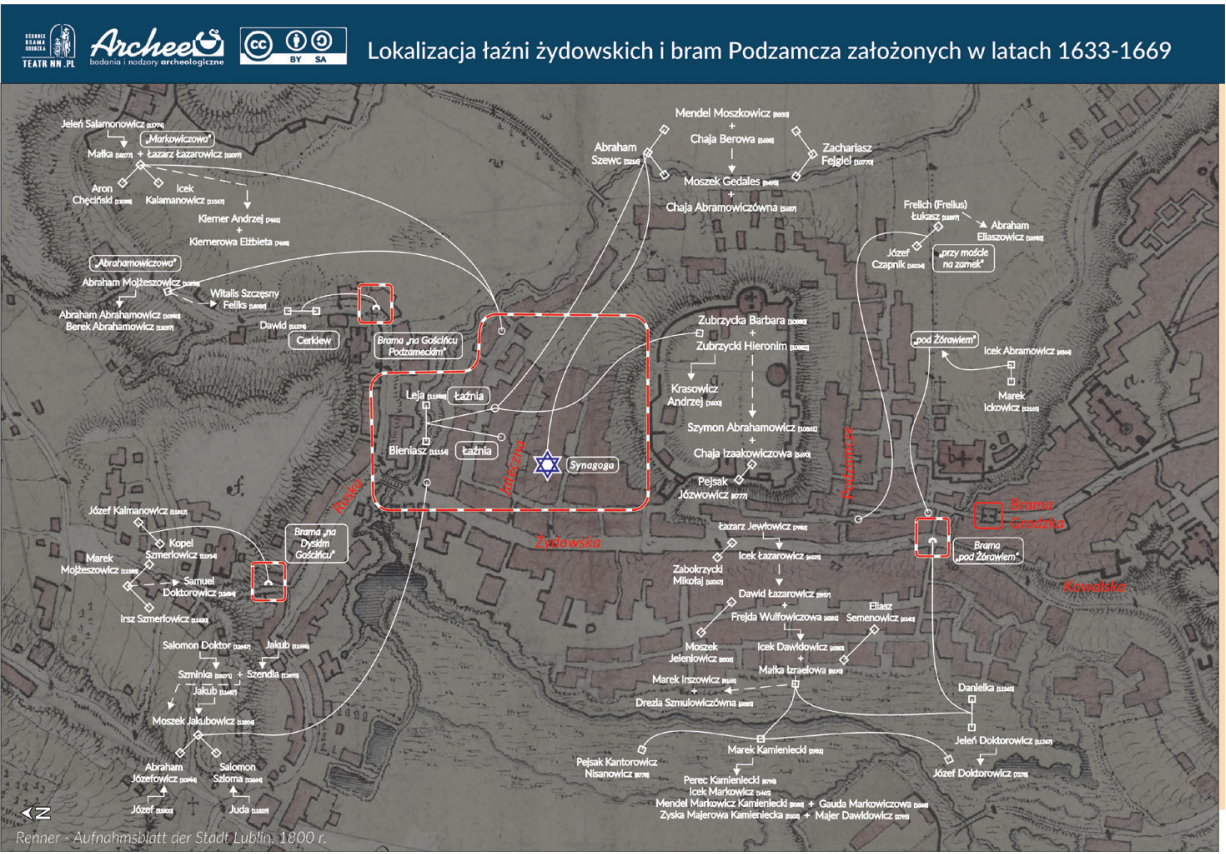

Il. 18. bramy i łaźnie 


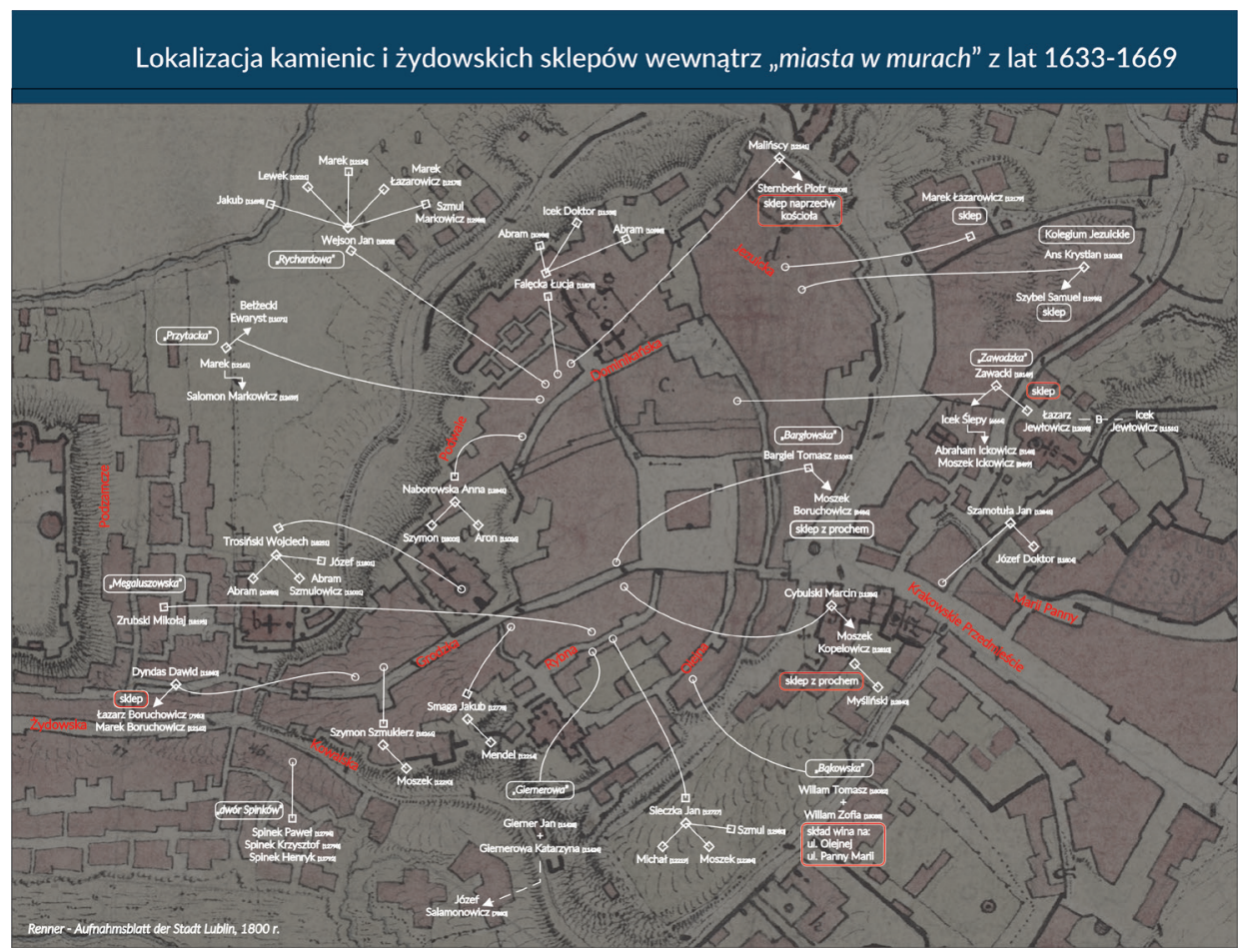

Il. 19. kamienice i sklepy 


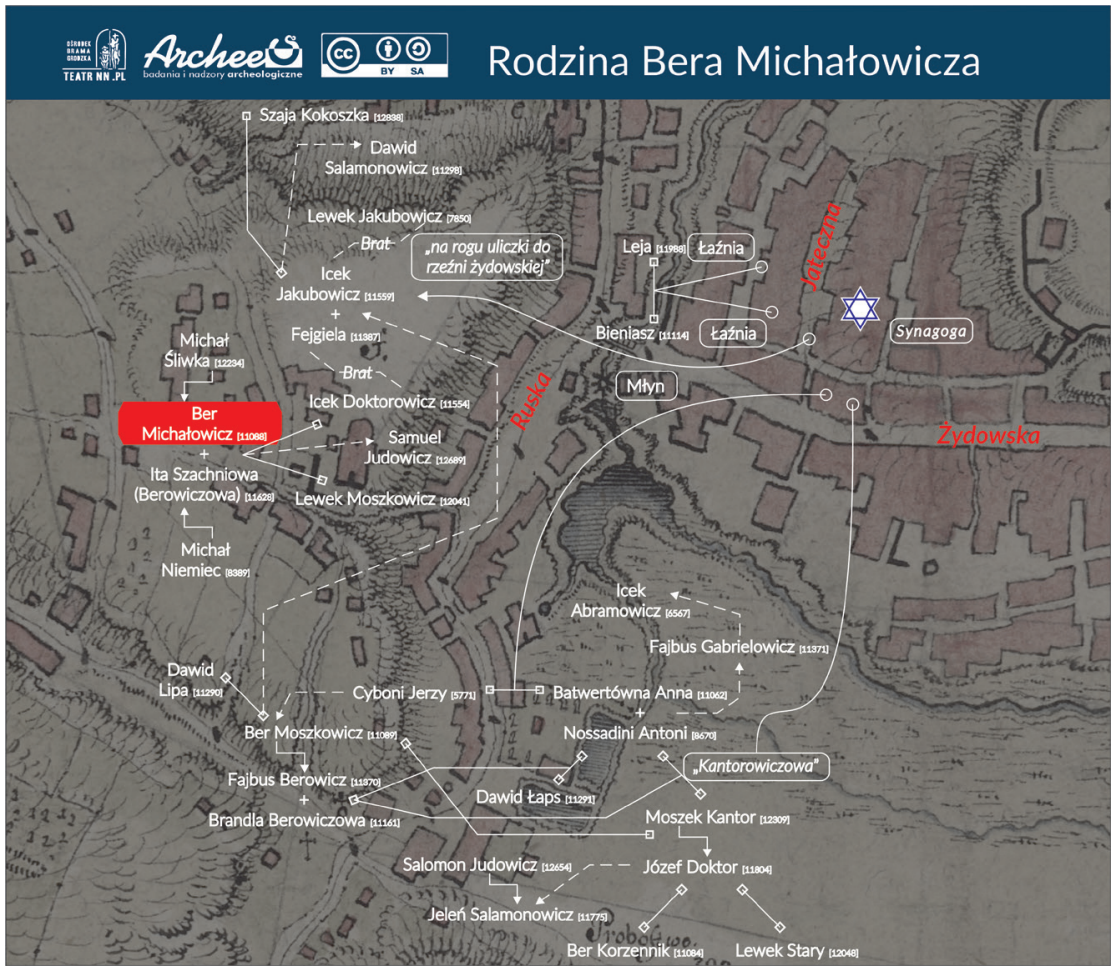

Il. 20. rodzina Bera Michałowicza

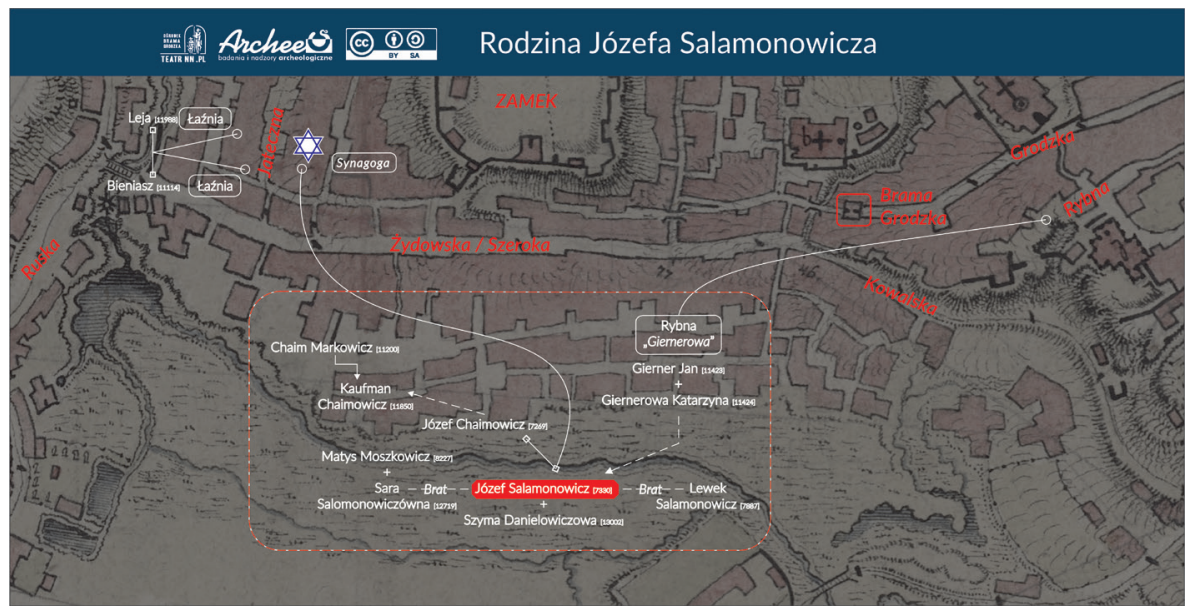

Il. 21. rodzina Józefa Salamonowicza 